\title{
HILAL BEY MOSQUE IN KŪM AL-NŪR, DAQAHLIA (EGYPT): A HISTORIC AND ARCHITECTURAL STUDY
}

\author{
Mohamed H. METWALLEY \\ Faculty of Archaeology, Aswan University, Egypt \\ E.mail: dr.mohamedhamdi82@yahoo.com
}

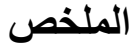

\begin{abstract}
This article documents and analyzes the $19^{\text {th }}$ century historic mosque of Hilal Bey mosque in al-Daqahlia, within the Egyptian Delta. It was built according to the Egyptian provincial 'local' pattern that prevailed in Egypt during the $19^{\text {th }}$ century onwards. The founder is Hilal Bey, a member of the Majlis Shura al-nuwāb at the time of Khedive Isma'il. The mosque was built, according to the existed foundation inscription in 1270

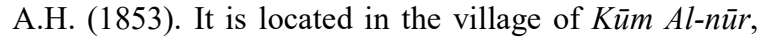
which belongs to the Mit Ghamr city at the province of al-Daqahlia, northern Egypt.
\end{abstract}

The plan of the mosque forms a rectangular prayer hall without courtyard. The prayer hall consists of three aisles 'riwaqs' divided by two arcades with pointed arches. The aisles are paralleled to the qibla wall; the middle one is wider. The ceiling of the mosque is wooden. The mosque has some annexes in its southeastern part, including an oratory, an ablution fountain, and toilets.

This article aims to highlight the historic and architectural significance of this mosque, by its comparison with other contemporary related mosques. It concludes with a recommendation to protect and to invest it as well.

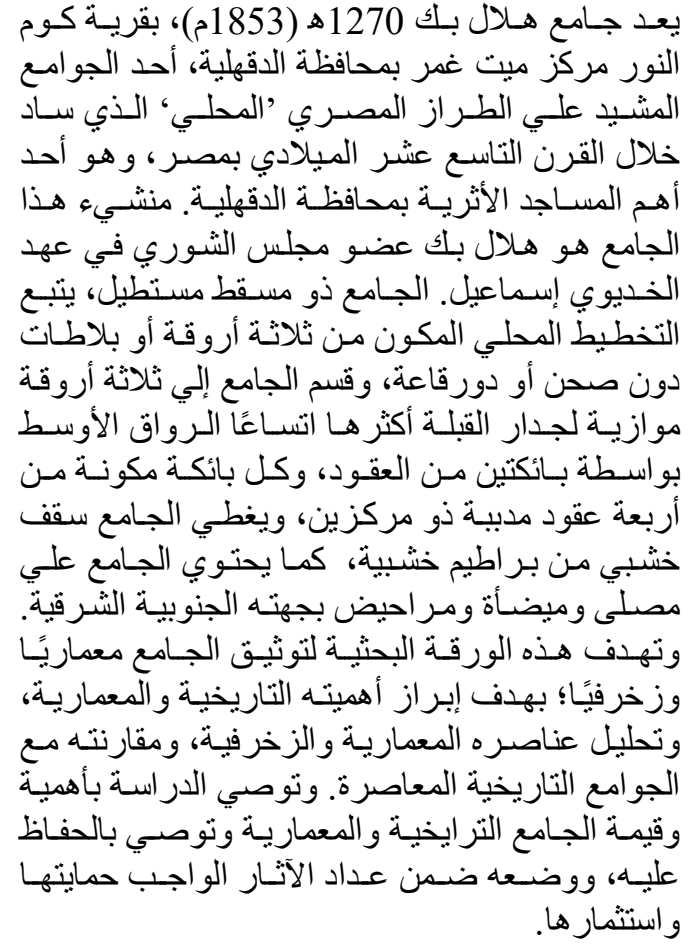

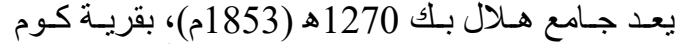

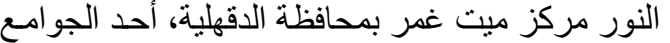

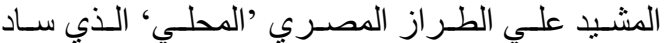

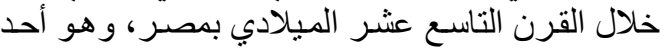

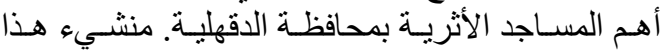

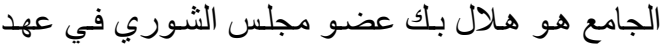

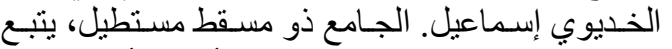
التخطيط المحلي المكون من ثناثة أروقة أو أو بلاطيات دون صحن أو دورقاعة، وقسم الجامع إلي ثلاثة أروقة الرقة

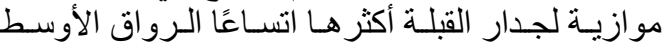

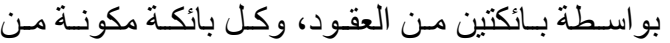

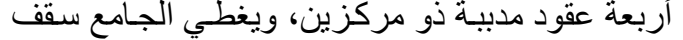

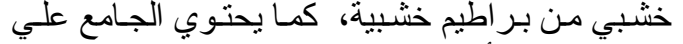

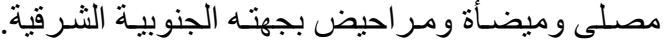
وتهـف هذه الورقـة البحثيـة لتوثيق الجـامع معماريًا

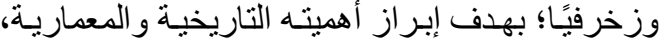

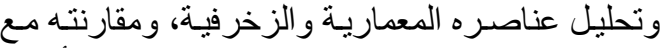

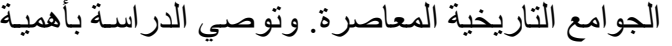

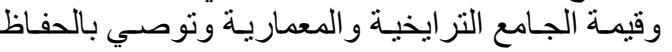

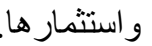
الكلمات الدالة KEYWORDS جامع، هلال بك، الدلتا، مصر، عمارة إسلامية، القرن 19م. Hilal Bey, mosque, Egyptian Delta, Islamic Architecture, $19^{\text {th }}$ century. 


\section{INTRODUCTION}

During the $13^{\text {th }}$ century A.H. (19 ${ }^{\text {th }}$ A.D.) many mosques have been built in the Egyptian Delta region. They, mostly, followed the Egyptian provincial 'local' style i.e. the mosques without courtyard, only a prayer hall divided into internal aisles 'riwaqs'. This plan was very common in al-Daqahlia region along with its towns and villages. In which is the mosque under discussion i.e. Hilal Bey Mosque, which is also known as the Bey "Bek" mosque. With the last name this historic building was registered in the record of the Islamic and Coptic monuments; as a result of the approval of the Permanent Committee for Islamic and Coptic Monuments in its session on 27/7/1999, and the approval of the Supreme Council of Antiquities' board in its session on 27/9/1999.

Almost there are no previous studies discussed the mosque under discussion; thus this article proposes a new documentation and an analyzed study of the Bey Mosque located in Küm Alnūr village at Mìt Ghamr, Daqahlia (Egypt).

\section{THE FOUNDER \& THE DATE OF CONSTRUCTION}

Hilal Bey ${ }^{1}$ was a member of the Majlis Shura al-nuwā $b^{2}$ from al-Daqahlia ${ }^{3}$ and al-Sharqia registrar ${ }^{4}$ in the Council ${ }^{5}$ at the time of Khedive Isma'il. ${ }^{6}$ The Egyptian parliament achieved a

\footnotetext{
${ }^{1}$ Bey is an old Turkish title, originally Persian, means a wise man or leader. For the Mughal and Turkmens, it is a title of honor. It equals "prince" for Arabs. The first holder of this title was Tughril Bey, the founder of the Seljuk Empire in 450A.H./1058 A.D. Then, its use prevailed to include princes and Sanjaks in the Ottoman Empire who were lower than Paşa. In the $19^{\text {th }}$ century, this title was awarded to many personalities, some of which were occupying administrative positions and others of the royal family. In the age of Mehmed Ali, this title developed to be an honorary title. For the military men, this title was given to those of Amiralay Kaymakam ranks. This prevailed in Egypt till 1914. It should be noted that owing to the Law of Egyptian Titles on January $8^{\text {th }}, 1923$, the previous decrees issued in 1914-1915 were canceled. This title was divided into two ranks. While the first rank (his excellenc was bestowed on the officials whose monthly salary was not below 1200 pounds, the other (saheb aleza) was bestowed on the officials whose annual salary was not less than (800) pounds and it was sometimes given to persons of distinction who did great services to the country. Alkhatib, Muajam Almuștalahat wa Al' lqab Altarikhia, p.83; Barakat, Alalqab walwazaif al 'othmania, pp.321-323.

${ }^{2}$ Throughout the Islamic and the direct Ottoman reigns, Egypt did not know representative councils. After the advent of the French campaign and the cultural shock, the Egyptians began to look for the West for imitation. Accordingly, the first sign of parliamentary life appeared in 1829 during the reign of Mehmed 'ali Paşa who established a council for discushions, comprising major traders, notable people, mayors, Shīkhs and scholars. Its main task was to express opions about the public administrative issues, but Mehmed 'alī was not obliged to implement them. In other words, it was only an advisory council. Owing to Mehmed 'alī, this council was introduced and its responsibilities developed that it was comparable to the Parliaments of Europe. After his death, this council became inactive because Abbas Ḥilmi I Paşa and Meḥmed Said Paşa were not enthusiastic enough for it. Alrafīy, 'așr Mehmed 'alī, pp.516-525.

${ }^{3}$ Daqahlia: Dakahla is an Egyptian city on a branch of the Nile. It is four leagues from Damietta and six leagues from Damera. It is a flourishing city. A district is added to it. Consequently, it is called Daqahlia district. Albaghdady, Moajam alboldan, Vol.(2), p. 459.

${ }^{4}$ al-Sharqia :It is called Sharqia because it is located to the east of Lower Egypt. In 1315, it was called Sharqia province, but in 1826 it was divided into small areas. In 1833, they were gathered to form one province, known as Sharqia directorate currently Zagazig. Ramzy, Alqamous Algoghrafi Lilbilad ALmiṣria min 'hd qodamaa ALmașrīn, vol.(1), p.75 and vol.(2), p. 22.

${ }_{5}^{5}$ Samy, Taqwim alnil, Vol.(4), pp. 672-674.

${ }^{6}$ Khedive Isma'il: He was called Isma'il ibn Ibrahim Paşa bin Mehmed 'alī Paşa, the second son of Ibrahim Paşa. He was born on December $31^{\text {st }}$, 1830 in Traveler's Palace. He traveled on an educational mission to Paris to study engineering, mathematics and physics. Additionally, he studied military arts in the military school founded by his grandfather Mehmed 'alī Paşa and joined the Special Military School of Saint-Cyr. After returning to Egypt at the time of his uncle Said Paşa and presided over the highest judicial authority, namely Majles Alahkam. On January 18, 1863, he came to power and he was deposed on June 26, 1879. Then, he moved to Constantinople, where he stayed till his death on March 2, 1895 at the age of 65. He was buried in
}

- 178 - Hilal Bey Mosque in Kūm Al-nūr, Daqahlia (1270 A.H/ 1853 A.D) 
significant leap with the establishment of Majlis Shura al-nuwāb $b^{7}$ in December 1866, comprising (75) representatives elected by the people of the large landowners each three years.

Hilal Bey, as a member of the Majlis Shura al-nuwāb from Daqahlia, played a prominent role in the first works of the Egyptian parliament (Fig. no.1). He suggested discussing the issue of "corvee" and mitigating its burdens. As a result, a committee was formed of the members of parliament to investigate the issue. It summoned 'alī Paşa Mubarak and Isma'il Paşa. The committee submitted a detailed report to organize the "corvee" on the basis of public interest, and that it was compulsory to the age group (15-50) years. Additionally, it was equal to all people. The council approved the report and its contents. Hilal Bey died in late 1905 in the reign of the Khedive 'Abbas hilmi II $^{8}$ (1892-1914).

According to the foundation inscription above the main entrance of the mosque ${ }^{9}$, it was founded in 1270 A.H. (1853). ${ }^{10}$
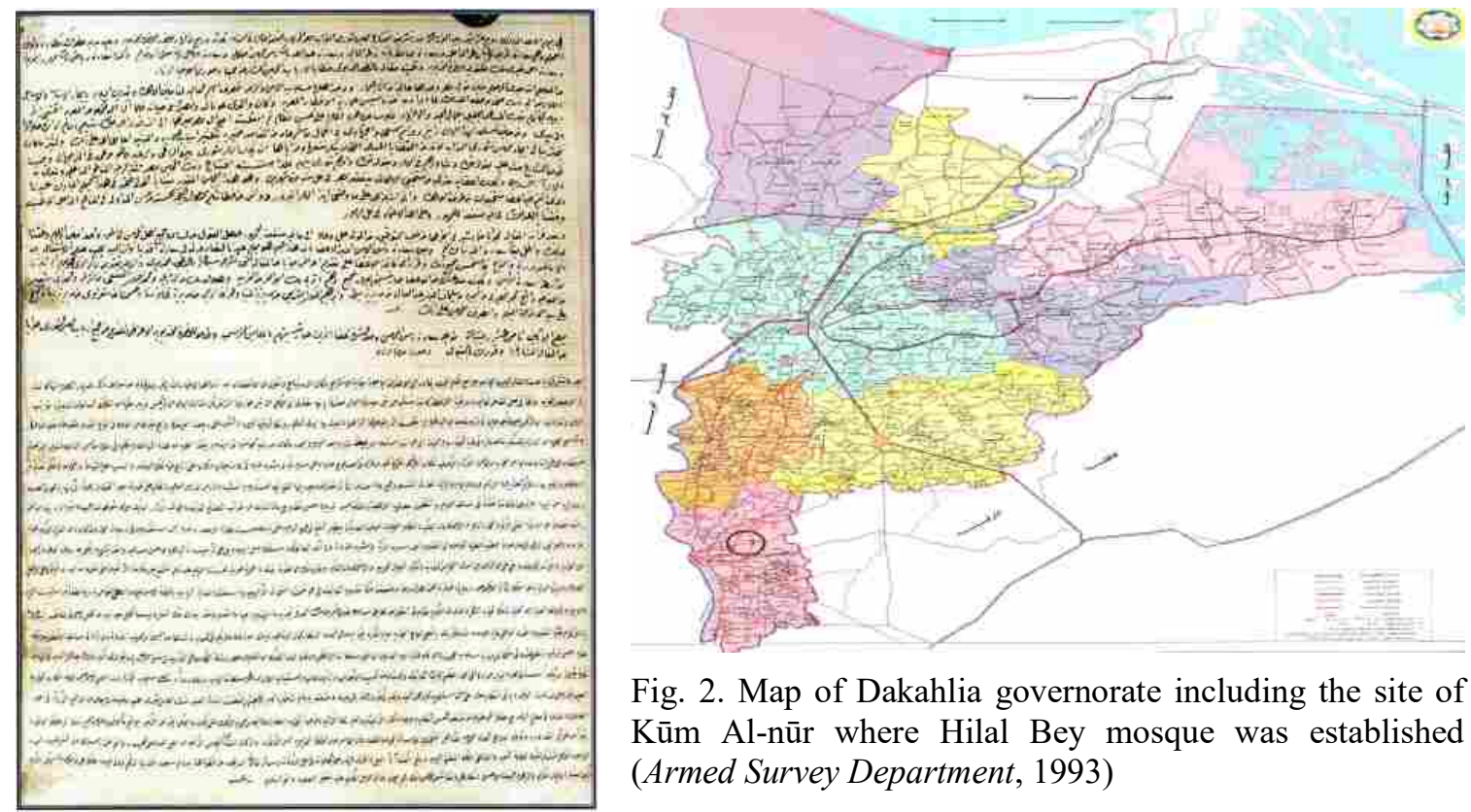

Fig. 2. Map of Dakahlia governorate including the site of Kūm Al-nūr where Hilal Bey mosque was established (Armed Survey Department, 1993)

Fig. 1. Minutes of the meeting of the opening session of Majlis Shura al-nuwab; in which Hilal Bey was mentioned (Azab, țahir and țahir, Egyptian Majlis Shura al-nuwab)

Alrefaey mosque, Egypt. Sabry, Tarikh Mịsr Alhadith, pp. 95-177; Zydan, Tarajim mashahīr a-sharq fi alqarn altasi' a'shar, Vol.(1), pp. 49:60.

${ }^{7}$ Khedive Isma'il had a real desire to engage the people, represented by the large landowners in expressing opinion in the issues of facilitating the work of the Egyptian government. However, this council was advisory not obligatory. It was established with the emergence of the Egyptian public opinion formed along with the Egyptian press and the liberation movement from the foreign intervention that was increasingly apparent by the end of Khedive Isma'il's reign.

${ }^{8}$ A report submitted to his excellence the Khedive by the mayor of Kūm Al-nūr regarding the village's status, Al Ahlia Press, 1914, p.4

${ }^{9}$ Samy, Taqwim alnil, Vol.(2), pp. 666-680; Alayoubi, Tarikh miṣr,Vol.(1), pp. 68-73; Allrafìy, 'Așr Isma'il, pp.88:112.

${ }^{1}$ In 1270 A.H. (1853), Khedive 'Abbas Hilmi I died on Shawwal 18, 1270/July 13, 1854 and Sa id Paşa came to power two days later on Shawwal 20, 1270A.H./ July 15, 1854.

Mokhtar, Altawfikiat Alilhamya, p.1315. 


\section{SITE}

Hilal Bey Mosque is located at 'Abdullah Bey St., ${ }^{11}$ Küm Al-nūr, ${ }^{12}$ Mìt Ghamr, ${ }^{13}$ al-Daqahlia. It was built on a land owned by the same founder, who was the mayor of Küm Al-nür and member of Majlis Shura al-nuwāa $b^{14}$ (Figs. nos. 2-3).

\section{THE EXTERIOR}

The Northwestern 'Main' Façade. It, as well as the other façades, was built from hewn yellowish limestone. ${ }^{15}$ It measures 19.35 meters in length and 6.47 meters in height. In its western part, the main entrance of the mosque is found, far a bit from the façade center. The main entrance is a monumental one ${ }^{16} 7$ meters in height and measures 3.88 meters across (Fig. 4, Pls. 1-

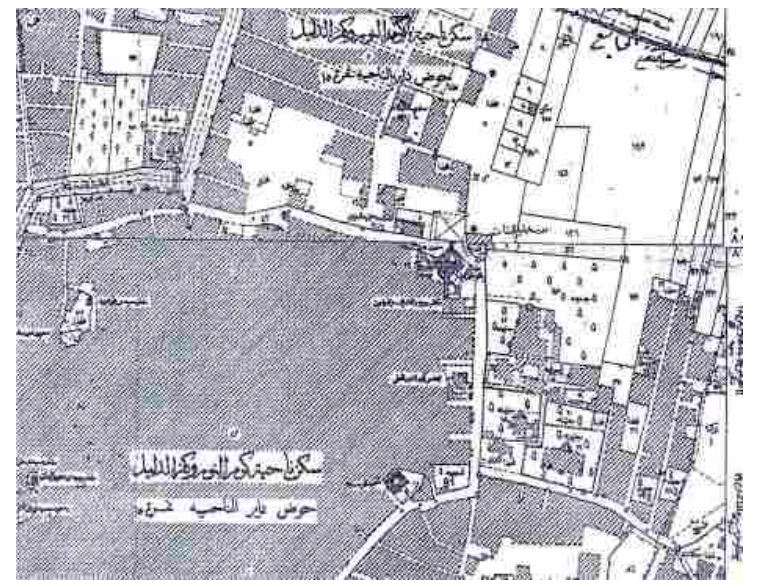

Fig. 3. Map of the Egyptian Survey Authority in 1935 on which the location of Hilal Bey Mosque was written. 2).

The portal protrudes 0.35 meters from the surrounding, and is a bit higher than the façade. The entrance opening measures 6.47 meters in height, 3.15 meters across and 0.57 meters in depth. The portal is crowned with a stalactite ${ }^{17}$ trilobed $\operatorname{arch}^{18}$. The arch is surrounded by an

\footnotetext{
11 Abdullah Meḥmed, mayor of Kūm Al-nūr and son of Hilal Bey. He was a second Lieutenant in the Egyptian army at the time of Abbas II hilmi. He was sent to war in Sudan and appeared in the Battle of Omdurman in 1899. He worked in establishing the streets of Khartoum and Alhalfaya. After three years in service, he resigned because of his father fell ill in 1901. As a result, he returned to Kūm Al-nūr and was elected the mayor early in 1905. His father died late this year. See a report submitted to his excellence the Khedive by the mayor of Kūm Al-nūr regarding the village's status, pp.3:11.

${ }^{12} \mathrm{Ku} m$ Al-nūr: It is an old village that was formed at the time of the Arabs on the ruins of an ancient one known as Alpoul. Alef and lam of Alpoul are part of the word not the definite article. After the destruction of the ancient village, a village appeared, namely Kūm Alpoul. As a result of founding the current village, the whole villages were united to form Kūm Alpoul. Because of not adjusting the word "alpoul", people thought that it was an etymology of urine. In the 6th Hijri century, the word was substituted with maa (water). Consequently, it became known as Kūm Almaa. Later, it was known as Kūm Al-nūr instead of Alpoul and Almaa. Ramzy, the author of the Encyclopedia of Egyptian places' names, argued that it was better known as Kūm Al-nūr because if it was altered in the Ottoman era, there was no need to call it Kūm Al-nūr. In the map of the Description of Egypt and in 1228, it was mentioned with its present name. In 1903, it was mentioned that it was separated from Kafr Eldalel and they were known as Kūm Al-nūr and Kafr Eldalel, as nearby places. Ramzy, Alqamous Algoghrafi, vol.(2), pp. 259:260.

${ }^{13}$ Mit Ghamr: It is an ancient village that was originally called Mineat Ghamr. In 1228A.H., its named was altered to Mìt Ford. Mineat hamad that was mentioned with Mineat Ghamr in Tuhfat Elarshad and Taj al-'Arus because they are in a nearby place. Then, they were combined to form Mineat Ghamr. In the Ottoman era, Mineat hamad was named Kafr Albatal after the prince hamad who was known as Albatal. Although, it was separated from Mìt Ghamr in 1228A.H., they were combined in 1903 to be known as Mìt Ghamr. In 1871, it became known as Mìt Ghamr locality. Ramzy, Alqamous Algoghrafi, vol.(2), p.263.

14 - A report submitted to his excellence the Khedive by the mayor of Kūm Al-nūr regarding the village's status, Al Ahlia Press, 1914, pp.4:5

${ }^{15}$ Limestone: It is composed mainly of calcite (calcium carbonate). It also comprises quartz, hematite and magnetite. It is a sedimentary rock that comprises skeletal fragments of marine organisms. Although it is white, it may be white, red or blue according to the type and percentage of sediments. 'Alī, Tarmim alṣouar aljidaria, p.24; hilmi, $\boldsymbol{i}^{\prime}$ Im alm'adin, pp. 319:322.

${ }^{16}$ The main entrance of the Mosque of al-hakim (380-403A.H/ 990-1013A.D) is the oldest relief monumental entrances in the Islamic architecture in Egypt. Alomary \& Alțayish, al'imara fi miṣr alislamīh,p.78.

${ }^{17}$ Stalactite is a decoration composed of pieces of stones. Its upper part is brought into view than the lower one. Corniches are put next to each other. It may comprise many layers. Therefore, it is used at the top of walls, squinches, windows and in the transition area of the dome. Stalactites take many forms, ranging from the local,
}

- 180 - Hilal Bey Mosque in Kūm Al-nūr, Daqahlia (1270 A.H/ 1853 A.D) 
interlaced band of carved stone "fret" ${ }^{19}$ that extends to frame the doorway. The spandrels of the entrance are decorated with a raised circular knot of a gear shape in the center, and a set of sides with interlaced ends. Additionally, frets surround the spandrels till the lower part of the entrance that also siege two parallel decorative bands carved in high relief. Each band comprises a decoration. Archaeologists identify it as a frame ${ }^{20}$ which is a form of geometrical ornamentations that takes the shape of ' $y$ ' letter (Fig. 6), known as al-kirandiz or al-kiranday. It is implemented in the upside and downside form, either reversed or parallel encompassing certain forms. It is used in making frames that surround the various ornamental formations. Each band is headed by a hexagonal shape including two octagonal stars. ${ }^{21}$ Each one is surrounded by two spears. ${ }^{22}$ There are two maksalas ${ }^{23}$ flank both sides of the entrance, each one is $57 \mathrm{~cm}$ in length $\mathrm{x} 45 \mathrm{~cm}$ in depth $\mathrm{x} 70 \mathrm{~cm}$ in height. In addition, it has two similar facades; each façade is decorated with a geometrical formation mainly consisting of a square or rectangular shape of protruded stone frames, ${ }^{24}$ known as a rib ${ }^{25}$ and a semicane ornament ${ }^{26}$ known as al-banuhat (Figs. 5-6, Pl. 3).

Arab or carinated. This form was introduced in the Ayyobid era in the dome of Abbasid Caliphs 640A.H./1242A.D. on Alasharf St. in the burial ground of Saeeda Nafissa. Amīn \& Ibrahim, Almoṣ̣talahat alm 'amaria, p.113.; Khalifa, Aldawr almi 'mary walfany llmoqarnasat, pp.5:6.

${ }^{18}$ Trilobed Arch: It is a local naming. It is known that the capitals of the Islamic Egypt (Fustat- al-'Askar- AlQațā' i- Cairo) may be called cities of Egypt because they varied, containing relatively close settlements. The word Almadainy was not named after Al-Mada'in that was about $35 \mathrm{~km}$ to the left southeast of the Tigris. The trilobed arches were introduced in Iran in the early $5^{\text {th }}$ A.H. $/ 11^{\text {th }}$ A.D. century in the mosque of Yazd in 429A.H./1037A.D. in the transition area of the dome. In Egypt, these arches were introduced toward the end of the $5^{\text {th }}$ A.H./11th A.D. century in the transition areas of the domes of Fatimid mausoleums and the windows and openings among them. Najib, Madrasit ala'mir Kabir Qirqmas, pp.199:209.

${ }^{19}$ Fret is a Persian word for a curve and two similar items. Architecturally, it represents an outstanding decoration that is carved in stone in the form of a frame or a chain, comprising two parallel lines that regularly intertwined. It is interspersed with hexagonal forms. In Egypt, it was introduced in the reign of Bahriyya Mamluks. It was implemented in the façade of the Madrassa of Sultan Hasan (757-762A.H./1356-1360A.D.). After that, it was implemented in the high relief form near the end of that era. Amīn \& Ibrahim, Almoștalahat alm 'amaria, p.29; Omara, Al'anasir alzokhrofia, p.21.

${ }^{20}$ Kishk, Ashghal alkhashab fi al'amair al'othmania, pp.164-414.

${ }^{21}$ Octagram: It is known as Venus star. It appeared on the Ottoman flag for a short time. The Arab think believe that it is a symbol that Allah's powers surpass those of nature. Zaki, Ala'lam wa sharat almulk fi wadi alnil, p.35; Bahnasi, Ma any alnujom, p.60.

${ }^{22}$ As an ornamental element, a spear was originally introduced in the Greco-Roman era when the artist used to make it of the crown of the ionic palmyra's snails. It also appeared in the architecture of Fatimid buildings where it was implemented on a frame circulating an arcade holing the dome in Al-Azhar Mosque 544A.H./1149A.D. Shaffi, Al'imara ala'rabia, p.113; Creswell, The Muslim Architecture of Egypt, p.231.

${ }^{23}$ Maksala is a stone seat. They were created on both sides of the deep entrances. They were called this way because of the lazy people who prefer to sit on them. Their oldest example in Cairo buildings was created on both sides of the entrance of Amir Alin Aq Palace (693A.H/1293A.D). Abulfitouh, Madakhil al 'm'ar almamloukia, p.55; Lam'y, Altorath alm 'mary alislami fi miṣr, p.9; Rizq, Muajam Mustalahat Al'imara wa Alfonon alislamīh, p.301.

${ }^{24}$ Using raised stone frames in the Islamic buildings known as al-banuhat dates back to the Umayyad era. A frame that takes the form of a thin projection decorated the only door that remained from the external wall of Eastern al-Hayr Palace in the middle of the Syrian desert 110A.H./728-729A.D. After that, it was implemented on the façades of the two towers of Bab al Futuh in Cairo 480A.H./1078A.D. and Bab Zuwayla 485A.H./1092A.D. Later, it was implemented on Bab Elmodraj in the Saladin Citadel of Cairo 579AH../1183A.D. Then, it spread on the Mamluk buildings of Cairo, e.g. the façade of Baybars al-Bunduqdārī Palace that was founded in the 7th A.H./13th A.D. century. Omara, Al'anasir alzokhrofia,Vol.(1), p.20.

${ }^{25} \mathrm{Rib}$ is the simplest types used as a line among the decorations, either in the flat or curved surfaces. It is also used in the beginning or end of a set of decorations. It is known by its width; narrow or wide due to a surface known as "sennah". Amīn et al., Fan albina', Vol.(1), p.151.

${ }^{26}$ The semi-cane ornament is a raised intertwined ornament used in flat or curved surfaces. If its size becomes bigger in the curved buildings, it is known as an anklet and if bigger, it is a tilsan. Amīn et al., Fan albina', Vol.(1), p.151. 


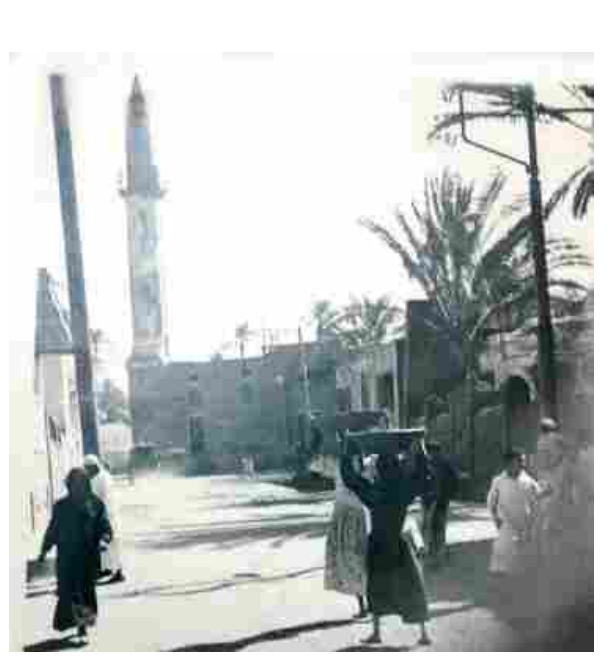

Pl. 1. An old photo Hilal Bey Mosque

(A report submitted to his excellence the Khedive by the mayor of Kūm Al-nūr).

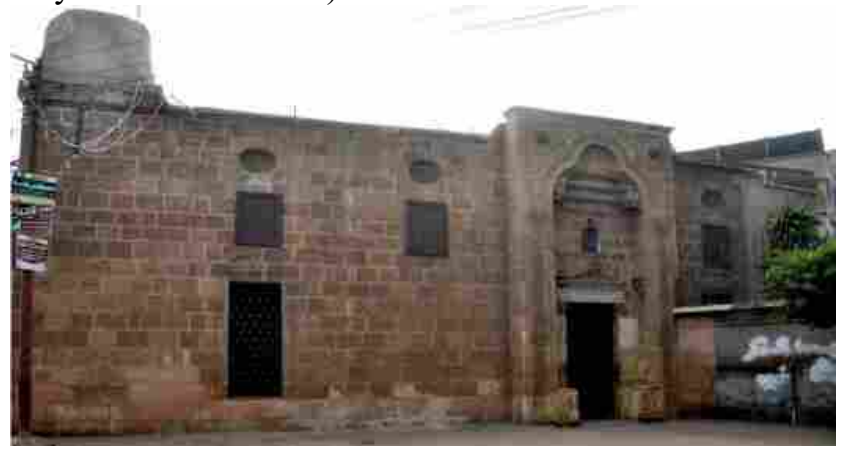

P1. 2. NW façade of Hilal Bey Mosque

(All plates and figures not followed by the source are of the author)

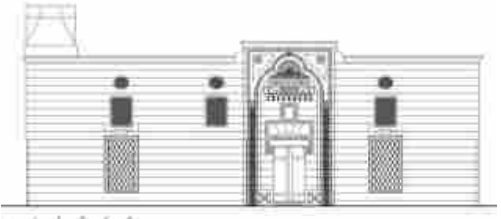

Fig. 4. NW façade of Hilal Bey Mosque

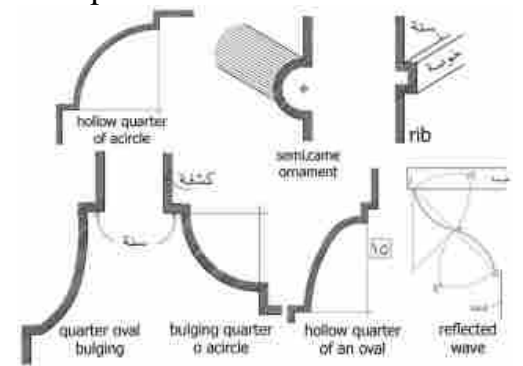

Fig. 5. Frames decorating Hilal Bey Mosque (Amīn et al., Fan albina')

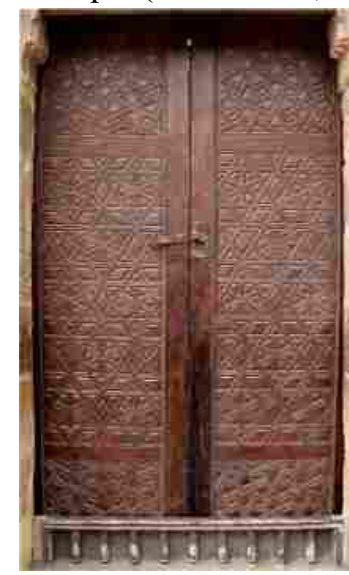

Pl. 4. The shutters of the main door of Hilal

Bey Mosque.

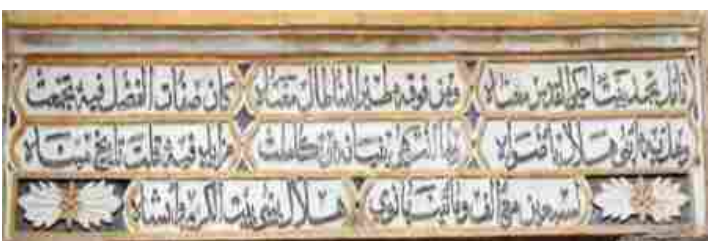

P1. 6. The foundation iscription of Hilal Bey Mosque.

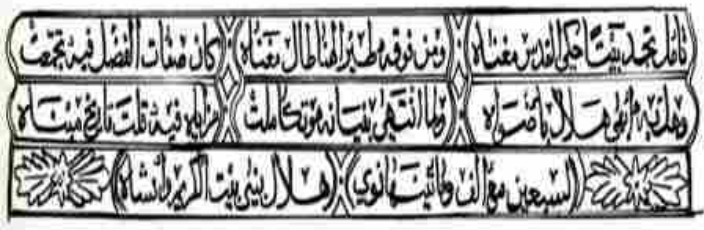

Fig. 8. The foundation iscription of Hilal Bey Mosque.

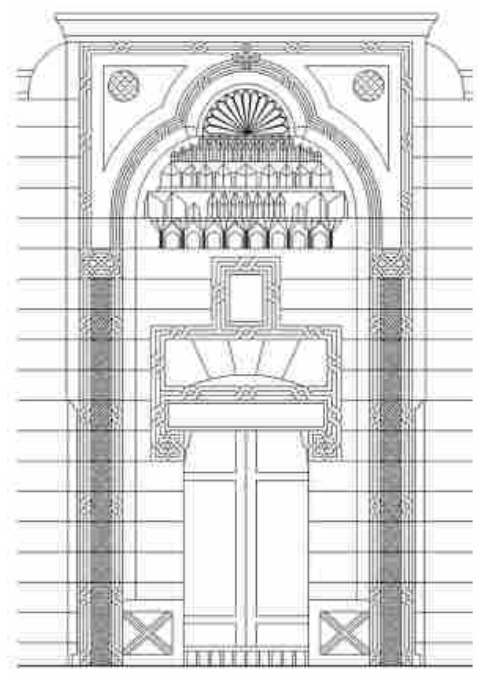

Fig. 6. The main portal of Hilal Bey Mosque.

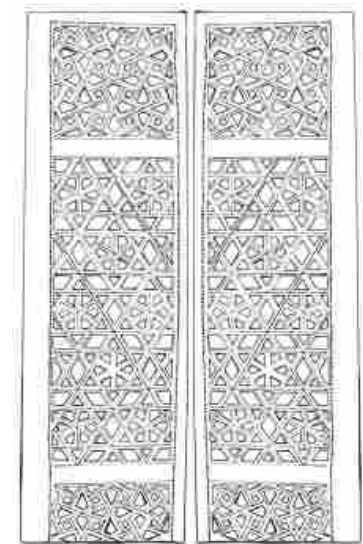

Fig. 7. The shutters of the main door of Hilal Bey Mosque.

The door opening measures 1.35 meters across and 2.58 meters in height. There is a wooden lathe barrier of $(25 \mathrm{~cm})$ in the lower part. The wooden barrier consists of nine wooden

- 182 - Hilal Bey Mosque in Kūm Al-nūr, Daqahlia (1270 A.H/ 1853 A.D) 
circular balusters. ${ }^{27}$ The shutters were made of oak, ${ }^{28}$ each of which comprises three interlaced ${ }^{29}$ panels. The largest is middle one that decorated with polygon ${ }^{30}$ 'hexagonal sarwa'. ${ }^{31}$ The polygons are separated by upside or downside equilateral triangles. Each triangle comprises three rhombuses in the three angles of the triangles. These rhombuses are separated by three small equilateral triangles. The upper and lower fillings of each shutter are identical in their decorative composition. In other words, they are mainly made of the inclined mafruk ${ }^{32}$ (Fig. 7, P1. 4). Above the entrance, there is a lintel of white marble on which the foundation inscription was carved in a high relief pattern. It comprises three lines: each of the first two lines consists of three cartouches ${ }^{33}$, while the third one of two cartouches only. The inscription was implemented in Thuluth script ${ }^{34}$ with the letters in dark blue on a white ground. The frames of the cartouches are golden. Two golden octal petaliferous rose flank the third line.

The foundation inscription (Fig. 8, Pl. 5) praises the building and the founder, and gives, in rhymes, ${ }^{35}$ the date construction and the founder's name, as follows:

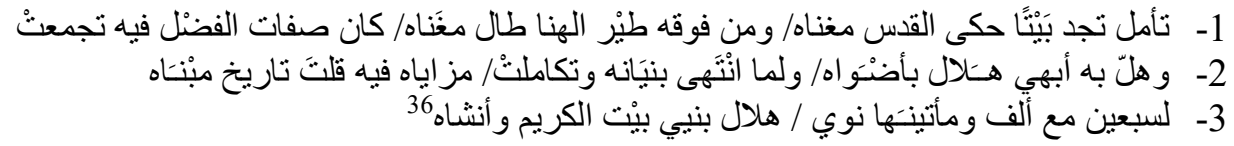

${ }^{27}$ Etymologically, wooden balusters are originally Turkish meaning finger to indicate to the spiral or cyclic sticks that are often made of wood. They are used in balustrades. They may be of square, rectangular, conical or spiral sections. Abdulhafiz, Almoștalahat alm 'maria, pp.29-30.

${ }^{28}$ Oak is exported to Egypt. Its trees grow in many parts of the world, including English oak which is characterized by durability and hardness. Also, there is a kind of oak characterized by shiny silver fibers resulting from the deployment of woodblock in a special way and it is expensive. Kishk, Ashghal alkhashab fi al'amair al'othmania, pp.79-80.

${ }^{29}$ Interlacing is making wood artifacts from small wooden pieces or panels of geometrical shapes in frames to form regular shapes, the most well-known of which is polygonal knotwork. It appeared in the late Fatimid era and the following eras. Fikry, Masajid alqahira wamadarisha, Vol.(1), p.16; Nașr, altuhaf alkhashabiah fĩ 'ṣr ușrat Mehmed 'alī, pp.190:194.

${ }^{30}$ A polygonal knotwork consists of the gear in the center and it is surrounded by a set of fillings in the form of small pointed almonds. It consists of four sides, known as the almond that consists a multi-sided star. It encloses a set of polygonal sides known as kinda . It was introduced in Egypt in the $6^{\text {th }}$ A.H./12 A.D. century in the mihrab of Elsayyedah Ruqayyah that is currently kept in the Museum of Islamic Art, Cairo. Altayish, Alfunon Alzokhrufia Alislamīh Almobakira, p. 20.

31 The latest example of polygonal knotwork is the coffin of Imam Shafi'I 574A.H/ 1178A.D. Abdulwahab, Tarikh almasajid alatharia bi-lqahira, Vol.(1), p.108; Hasan, Fonon alislam, p.462; Hasan, Ațlas alfonon, p. 376.

${ }^{32}$ This decorative element was modeled after the Greek swastika that moved to the Roman and Sassanid styles. It is oldest example in Iran in the Sassanid era is plaster artifact kept in the Metropolitan Museum of Art. Later, this decorative element moved to the Islamic art. A plaster artifact was found in Fustat that dates back to the early Islamic era. Furthermore .Shaffī, Al'imara ala'rabia, p.95\&217; Kishk, Ashghal alkhashab fi al'amair al'othmania, pp.157:158.

${ }^{33}$ Zawiat hasan Al-Rumī 929A.H./1522A.D. is considered the latest architectural example in Egypt in regard to the foundation texts that use lines and meters. Barakat, Dirasat alkhat wa-lalqab wa-lmanașib, p.158.

34 Scholars differed regarding the naming of this script. Undoubtedly, it has this naming because of comparing the size of Thuluth to that of Scroll. While Thuluth is written with a pencil of 8 palm felts, that of Scroll is written with a pencil of 24 . It is characterized by serenity, persistence and diversity in the thickness of letters as they end with a thin part. Dawood, Alkitabat ala 'rabia 'la al'thar alislamīh, pp.58-60.

${ }^{35}$ On analyzing the lines of the foundation text, it is found that the poet says "observe the mosque that you may find a place similar in holiness to that of Al-quds in blessing and purity. Birds fly over the mosque chanting in a manifestation of peace and satisfaction as if it combines all features of good and vitues, as well as others. Additionally, the most beautiful crescent topped it to reflect its colorful lights. By completing its architecture, all the good features were merged and it was completed in 1270 by Hilal Bik".

36 - The foundation text of the mosque contains the date of establishment in two ways. While the first was in letters, the second was in hisab al-jumal, as follows:

Naūa + hilal + ban̄̄ + bait + al-karīm + wa' nshahu

$66+66+62+412+301+363=1270$ A.H. 
Transliteration:

1- Ta' mal tajid baītan haka al-Qudsu ma nahu/ wamin fawqihi țairu al-hana țala maghnahu/ k'na șifatu al-faḍlu fïhi tajam't

2- $\quad$ wahala bihi 'bha hilalun bi-aḍūahu/ walamma 'ntaha bonīanuhu watakamalat/ mazaīahu fïhi qultu al-tarikh mabnahu

3- $\quad$ lisab 'ĩna ma 'a alfin wam' tīnha nawa/ hilalu bana baītu al-karīmu wa' nshahu

The opening door is crowned with a marble flat arch; above which is a tympanum 'nafees', then a relieving $\operatorname{arch}^{37}$ An interlaced carved stone band 'fret' frames the previous composition. The stone vousoirs of the aforementioned relieving arch is decorated in high relief with geometric patterns; consisted of simple polygons. Above the relieving arch, and beneath the portal's trilobed arch, is a rectangular window $(52 \mathrm{~cm}$ in height and $35 \mathrm{~cm}$ across) with well carved ${ }^{38}$ and decorated wooden grills. This window is also framed by an interlaced carved stone band 'fret' (Fig. 9, Pl. 3)

The façade's windows come in three tiers. Windows of the lower tier are rectangular (2.23meters in height and 1.11meters across) with stone frames, covered with iron gratings, and crowned with flat arches; above which is a tympanum 'nafees', then a relieving arch. The stone frames are decorated with a geometric tinsel 'torsades'. ${ }^{39}$ The latter consists of two intersecting lines enclosing rhombuses carved on the stone (Fig. 9, Pl. 6). The windows of the second tier are also rectangular (1.17 meters in height and 0.82 meters across), covered with inclined lathe ${ }^{40}$ wooden grills; consist of four octagonal ${ }^{41}$ shapes that enclose a silver cross (Fig. 10, Pl. 7). The windows of the upper (third) tier are oval, near to a circle, covered with modern metal wires. It is worthy noted that the three tiers windows of the western corner of this façade have been recently plugged up with cement inside and outside. But the lower window direct northern the main entrance, was originally plugged up; providing an internal closet, as certified by an old photo. The façade is topped with a protruded stone

\footnotetext{
${ }^{37}$ The relieving arch is composed of an arc of the circumference. It is also-called the relieving. It is a part of a circle to relieve the loads on the lintens for their safety. It was used in the classical Roman architecture. Its oldest example in the Islamic era was found in Qașr al-Hayr al-Sharqi 110A.H./728-9A.D. Alkasbany, Tațawr nuzum ali'mara, 1993, p.74.; Hasanin, Ashghal alrukham fi al'mara aldinia fi Madinat alqahira, p.98; hamdy, dirasa fi ali'mara alislamīh, p.91.

${ }^{38}$ It is the piercing of different decorations in wood by defining them in certain places. Then, the undecorated (ground) parts are pierced that separate the decorative units. It is hard to define where and when this mood began. However, when reviewing the ancient Egyptian heritage, 3000 years ago, the old Egyptian furniture included them and shell and ivory was used. Furthermore, furniture covered with these decorations was used in the European and Scandinavia countries in the $16^{\text {th }}$ and $17^{\text {th }}$ centuries. In the $18^{\text {th }}$ century-Europe, furniture works evolved and became well-known. Abuhashim, Fan ala'rkt, p.11; Kishk, Ashghal alkhashab fi al'amair al'othmania, pp.130:1

${ }^{39}$ They are well-known decorative elements since the ancient times in Iraq, Egypt and the Greek era. They were also used in the Islamic arts in the Fatimid ceramic of metallic luster. Shaffi, Al'imara ala'rabia, p.217; Hasan, Ațlas alfonon, p. 39.

${ }^{40}$ It is called this way when the leaves are taken off from trees. It is used as turning wood in the Islamic architecture when the wood takes the form of small rectangular or square pieces joined together to take the form of geometric shapes and they are fixed on the outer openings to prevent those outside the place from seeing what the details of what goes on inside, but not vice-versa. However, they do not block light or air. Amīn \& Ibrahim, Almoṣtalahat alm 'amaria, p.40; I'zzat, Tarikh alathath, p.145; Nazīf, dirasat fì al'imara alislamīh, , pp.256:258.

${ }^{41}$ It is composed of tiny pieces of wood where the carpenter fixes them upon each other according to certain spaces, taking the form of a right angle. The light emanating from the space among the wooden pieces takes the form of an inclined octagon. Abubakr, Almanabir fi miṣr, p.223.
}

- 184 - Hilal Bey Mosque in Kūm Al-nūr, Daqahlia (1270 A.H/ 1853 A.D) 
moulding 'cornice' of double bands; the lower called a 'rib' and the other known as a reflected wave (Fig. 5). ${ }^{42}$

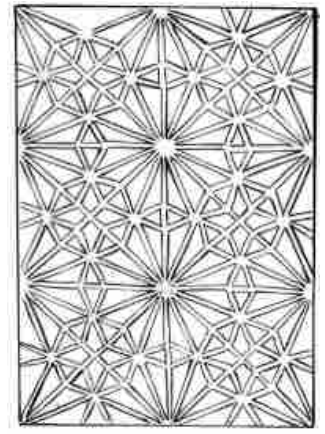

Fig. 9. The window above the foundation inscription

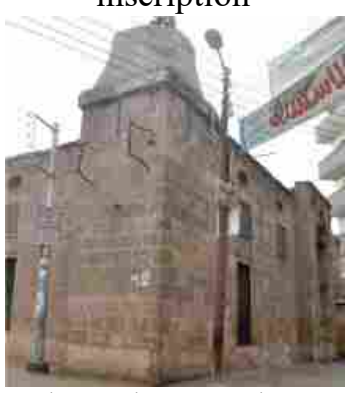

Pl. 8. The Noerthern corner of Hilal Bey Mosque (the minaret)

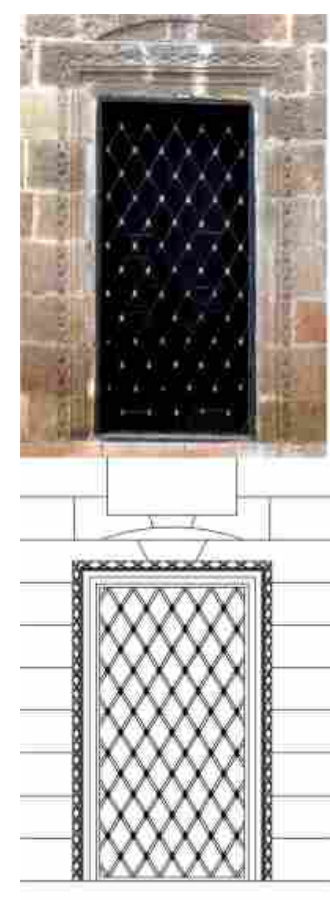

Pl. 6 \& Fig. 10.. The lower window of the NW façade

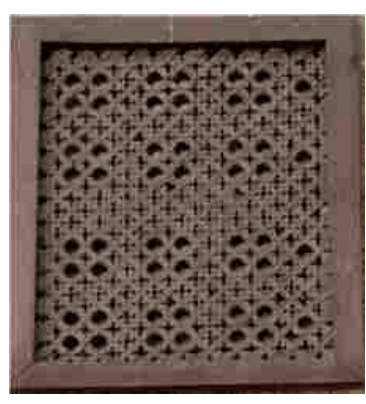

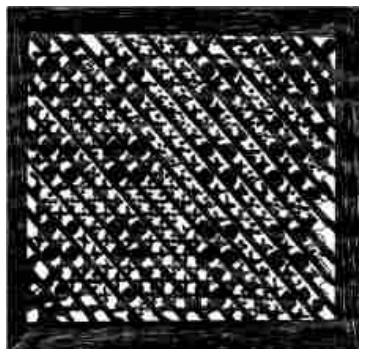

Pl. 7. \& Fig. 11. The rectangular window with its lathe wood in the NW facade

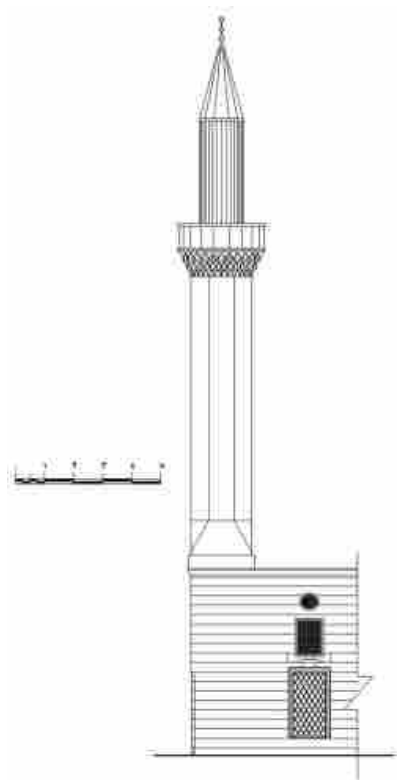

Fig. 12 :The minaret of Hilal Bey Mosque

\section{THE MINARET}

The upper part of the minaret collapsed result of the earthquake that struck Egypt in 1992; and only its lower part exists. The minaret occupies the northern corner of the mosque; which locates the intersection of the northwest and northeast façades. As the minaret appears in an old photo; it was Ottoman style. Its stone base is has a rectangular plan: 2meters by 1.26 meters, and raises 6.47 meters in height. The architect was keen on cutting the edges of the minaret's base, specifically at the intersection corners of its walls. It is crowned with a linear camel neck arch engraved in stone. ${ }^{43}$ The architect was keen on cutting the edges ${ }^{44}$ of the minaret's base in order to respect the streets' plan 'khat tanzim altariq'. The minaret's

\footnotetext{
${ }^{42}$ It is an ornament that consists of a blowing curve above a hollowing out one. Amīn et al., Fan albina', p.154.

${ }^{43}$ It is a developed form of arches that was taken from two Gothic arches in the Ottoman architecture, namely gooseneck and squinch arches. There is a top like the gooseneck arch that is based on the buttresses of two other arches. The camel neck arch differs from the gooseneck one because it is circular, not lancet. This type of arches is ornamental, rather than being architectural as it does not help carry the ceiling or other items of the building. Alkasbany, Tatawr nuzum ali 'mara, pp.273:4.; Nigm, Altoroz alm'maria walfania, pp.459:460.

${ }^{44}$ Cutting the edges of the minaret's bases to respect the traffic was carried out because of the narrow main and subsidiary roads, as well as many twinings in lanes and routes. It also might help protect the building because of the passing of carriages. Additionally, it gave more space to the road, especially in narrow lanes and routes. One of the oldest forms of this treatment in the Islamic buildings dated back to the Ahmad ibn Tulon mosque that was established in the Tulonian age. The builder cut the edges of stone props from inside to get rid of the sharp edges of the building in order to provide more width and space, to help the worshiper see the imam in the mihrab and the orator on the pulpit from any position, to decrease the size of the prop itself and to provide the largest amount of light in the kiblah. Alkihlawy, Athar mora'at itjah alqiblah wa khat tanzim altariq, pp.134:5.
} 
base is topped with the same moulding as the main façade. The minaret's door almost centers its southwestern wall; it has a rectangular opening 2.16 meters in length and 0.78 meter across. Above which, is a small rectangular window 1 meter in height and 0.5 meter across. The door leads to stone stairs that torsade on a cylinder pier and they, in turn, end with a wrecked door at the top of the mosque. Above the minaret's base, there is a transition area; has also a square plan (2.10 meters in height), built of brick, that was covered with a layer of mortar. The top parts of the corners of this transition area form inverted sliding triangles. ${ }^{45}$ The rest of the minaret is wrecked. A 1990s provides the description of the minaret. There was an octagonal shaft above the aforementioned base. Which topped an octagonal şerfe rests on stalactites. There were arched openings that ventilate and light the interior of the minaret. Above this shaft another shorter and more slender octagonal storey, then the conical top of the minaret (Figs. 12, 16, Pls. 1, 8).

The Southeastern Façade 'qibla wall'. It measures 19.35meters in length and 6.47meters in height. A part of this façade has been recently covered with mortar. In its mid, there is the projection of the buffet of the mihrab. ${ }^{46}$ It is a semicircular and ends with a semicircular small window and at its top there is an oval window covered with modern metal wires. The inner part of the oval window is decorated with a protruded stone band. On each side of the projection, there are two vertical rows of windows that are similar in the architectural and decorative elements. But it is noted that the three windows southern the mihrab have been recently plugged up with cement inside and outside. Regarding the lower windows in this façade are plugged up since the construction of the mosque providing a bookstore " $k u t b i \bar{a}$ ' instead of the window (Pls. 9, 21). Attached to the southeast façade from the eastern side, there is a recent room for the officials of the Ministry of Antiquities and beside it the burial ground $^{48}$ of Shīkh Khalīl al-hajrasi ${ }^{-49}$ (Fig. 16). In addition, the oratory is attached to the southeast façade since the time of construction the mosque. This façade is topped with the protruded stone cornice as the one of northwest façade (Fig. 13, Pl. 9).

The Southwestern Façade. It measures 13.21 meters in length and 6.47meters in height. This façade has been recently covered with mortar. In its mid, there is a rectangular door opening of 2.38 meters in length and 1.30 meters across. It links the mosque with its annexes: the oratory, the lavatory and the latrines. Above the door, there is rectangular window, upon which there is an oval lunette. Only a window was created on the right side of the entrance and above it there is another oval lunette. All the windows and small windows

\footnotetext{
${ }^{45}$ The western minaret of Sulțan an-Nasir Meḥmed - Qalawūn Mosque (735A.H./1334A.D.) in the southwest square of the Saladin Citadel of Cairo contained the first right-angledtriangle of these sliding triangles in the architecture of minarets. Mousa, Tatawr alm'zana almișria bimadinat alqahira, pp. 580\&720.

${ }^{46}$ The architect tended to support the mihrab with an outside projection because of the depth of the mihrab's buffet. Such depth in the mihrab causes an architectural defect in the wall of the kiblah. It was also created in the façade of the kiblah wall in Egypt in the mosque of al-șaleh țal' bin Ruzīk (555A.H/1160A.D.), the cemetery, and Iwan of al-tha liba 613A.H./1216 A.D. and the dome of Shajar al-Dur 648A.H./1250A.D.

${ }^{47}$ Architecturally, the bookstore is a rectangular opening in the wall. It is divided into higher and lower levels using a middle shelf to be ultimately utilized. In the first row (ground), is used to keep books and other items and the middle one is used for the same purpose. This opening is often closed by two wooden decorated shutters. Najib, Madrasit ala'mir Kabir Qirqmas, p. 210.

${ }^{48}$ Establishing a burial ground instead of a mausoleum was introduced for the first time in Egypt in the burial ground attached to the mosque of Prince Manjak Alyoussfi in Alhataba 750A.H./1349A.D. Ibrahīm, Ala'thar alislamīh albaqia bi-sharq aldelta, p. 217.

49 He was an ascetic and one of the great scholars of Al-Azhar. He was born near the end of the $12^{\text {th }}$ century in 1195H./1781A.D. He was brought up by his uncle Mehmed al- hifnawī al-hajrasī. He was one of the closest students to Shīkh 'bdullah hijazī al-sharqawī. At the age of 16, he learned the Holy Qur'an by heart and mastered the modes of recitation and principles of Sharia sciences. His uncle sent him to Shīkh Eldamhohy who taught him and after the death of this sheikh, al-hajrasī became the Shīkh of the Khalūtī order. He died on 10 Rajab 1269H./18 April 1853A.D. Alboghdady, Hidiat Al rifin, Vol.(2), p.391.
}

- 186 - Hilal Bey Mosque in Kūm Al-nūr, Daqahlia (1270 A.H/ 1853 A.D) 
of this façade resemble those of the northwest one in the architectural and ornamental contexts. Additionally, the southwest façade is topped with a protruded stone cornice that resembles that of the northwestern façade (Fig. 14, P1. 10).
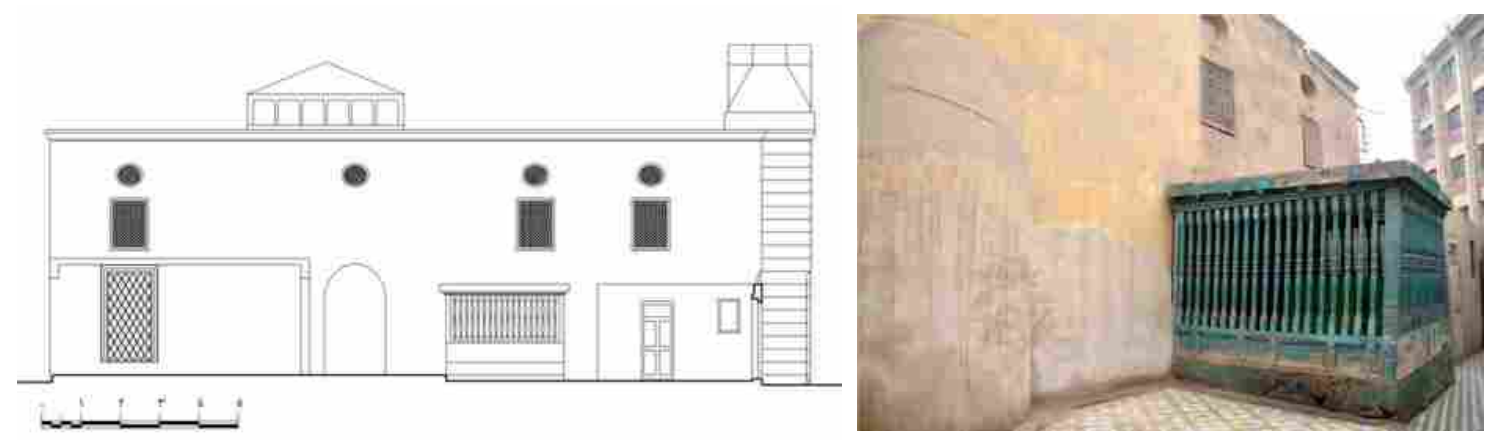

Fig. 13 \& Pl. 9. SE façade of Hilal Bey Mosque

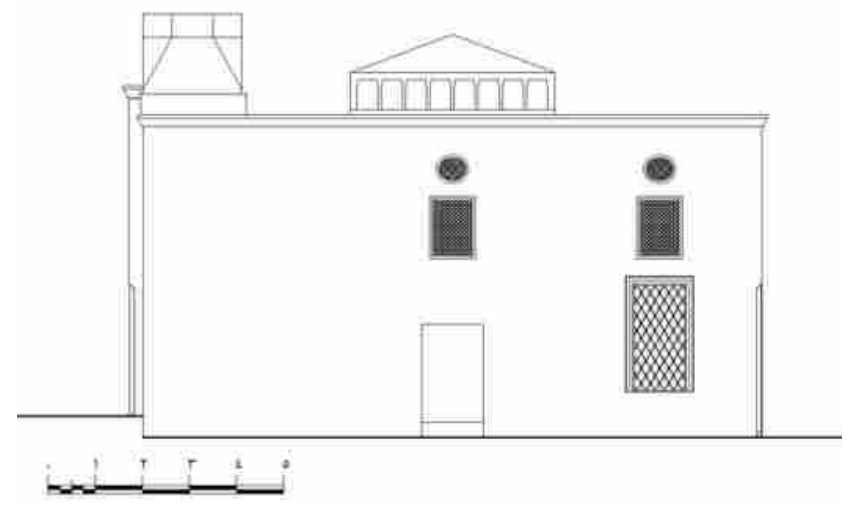

Fig. 14 \& P1. 10. SW façade of Hilal Bey Mosque
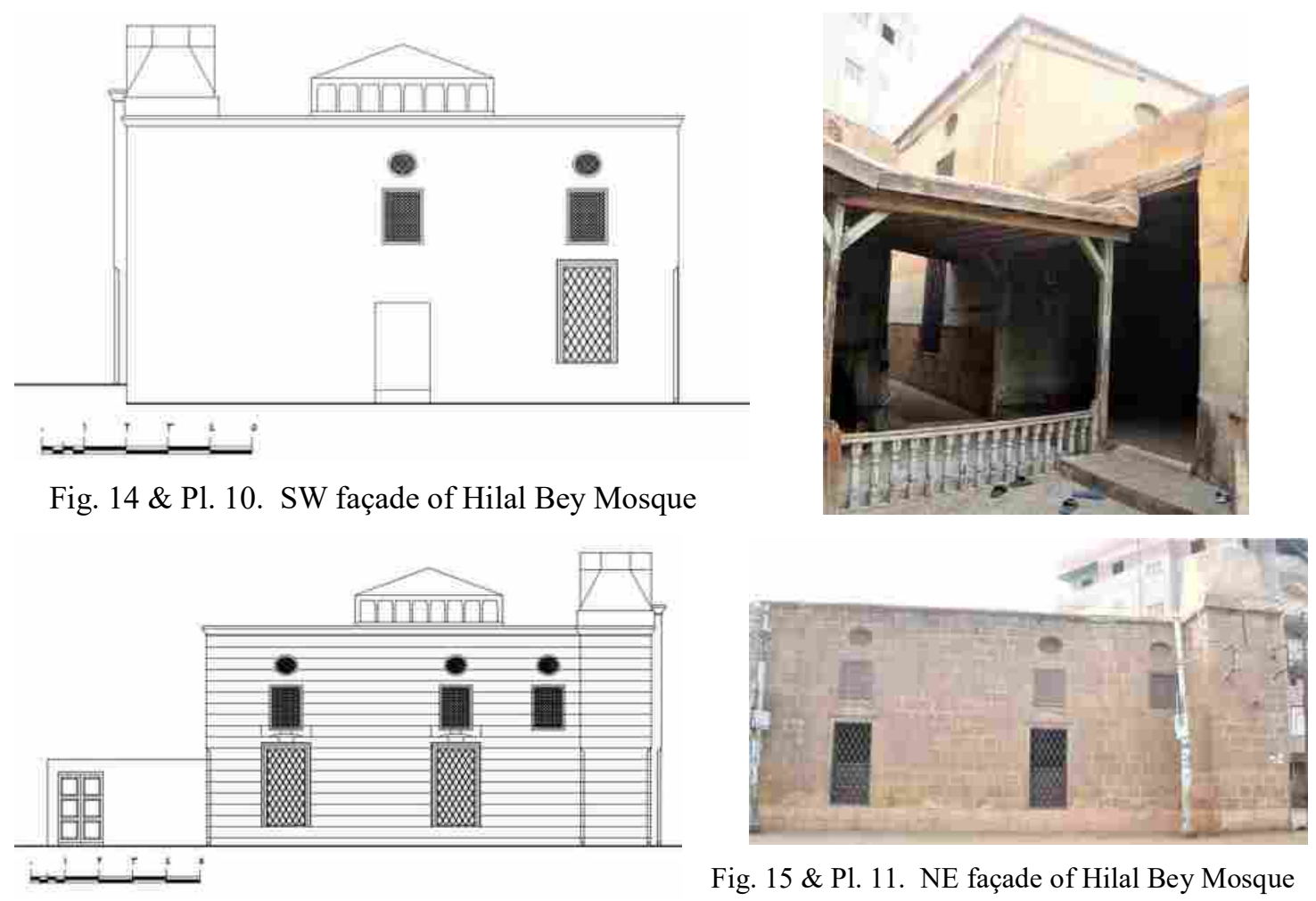

Fig. 15 \& Pl. 11. NE façade of Hilal Bey Mosque

The Northeastern Façade. It measures 13.21 meters in length and 6.47meters in height. It has three vertical rows of windows that each of which comprises three windows, but the middle one next to the minaret encloses two tiers of windows only. All the windows and small windows of the northeast façade resemble those of the northwestern one in the architectural and ornamental contexts, with the same topped stone cornice (Fig. 15, Pl. 11).

\section{THE ENTERIOR}

Accessing the prayer hall is through the entrance that almost in the mid of the northwestern façade. ${ }^{50}$ It is a form of direct pivot entrances. The prayer hall has a rectangular plan ( 19.35 meters by 13.21 meters); divided into three aisles paralleling the qibla wall. The

\footnotetext{
50 Abdulsattar Maḥmoud recorded a summarized architectural description of Hilal Bik Mosque. Alnīry, dirasa tariykhyh atharyh limuhafazat aldqhilyah, pp.274:5.
} 
largest aisle is the middle one (4 meters in width), while the other two aisles are 3.44 meters in width. Two arcades (Figs. 16-17, Pl. 12) dividing the aisle; each arcade consists of four pointed arches, that of two centers ${ }^{51}$ with 3.67 meters span, rest on three marble columns (3.37 meters in height) and the side wall on two stone pilasters. ${ }^{52}$ The arcades' columns are different; each one of the first arcade, towards the qibla wall, consists of a square base, decorated with protruded marble frame 'rib', then the column's cylinder shaft that of onyx marble. ${ }^{53}$ The upper and lower parts of the column are decorated with raised marble ornaments. The capitals are composite style ${ }^{54}$ (Fig. 18, Pls. 13-14). The $2^{\text {nd }}$ arcade columns consist of a bell-shaped base, a cylindrical shaft of onyx marble, and the capital. From the upper and lower parts, the column is encircled with protruded and similar marble decorations. The capitals are Corinthian ${ }^{55}$ (Fig. 18, Pls. 15-16). Above these capitals there are wooden abacus; on which rest the arches of the aisles, reducing the pressure ${ }^{56}$ of the heavy ceiling. There are wooden tie beams ${ }^{57}$ are connecting the arcades' arches with the walls; to ensure equal distribution of loads on walls, and to enforce the arcades, with an additional secondary function, for hanging the means of lighting. The spandrels of each arcade enclose three open circular lunettes whose diameter is $(40 \mathrm{~cm})$ in order to mitigate the pressure of the ceiling on the arches.

Qibla wall. The southeastern wall 'qibla wall' measures 16.84 meters in length and 6 meters in height. The lower parts of this wall, as well as the all walls of the mosque are coated with yellowish moulded stone building ${ }^{58}$ up to 1.25 meters in height. Beneath this stone lower

\footnotetext{
${ }^{51}$ The oldest example of such arches is in the Umayyad Mosque, Damascus 88-96H./707-714A.D. in the façade of the transept looking over the courtyard. It was claimed that this type of arches was created in the Pre-Islamic Era in Qașr Ibn Wardan 560-564A.D. in the Levant. However, it was argued that it appeared in the famous Sassanid monument of Khoșrow palace in Al-Mada'in. Shaffi, Al'imara ala'rabia, p.207.

${ }^{52}$ It is a projection that is meant to make it larger to increase its robustness, to distribute a larger burden, including arches...etc on the wall, to prevent the wall from being wrecked or to decorate it. Amīn et al., Fan albina', p. 36.

${ }^{53}$ It is a type of marble of various colors. It is known as fat and meat because of its incitement or it resembles onyx that is used in making beads. Saudy, Alrukham fi miṣr fi 'ṣr dawlat almamalīk albahria, p.20; Hasanin, Ashghal alrukham fi al'mara aldinia fi Madinat alqahira, p.28.

54 The Roman architecture utilized the styles of the Greek columns (the Tuscan, Dorique and ionic) and two other orders were added that were originally inspired by the previous three ones; the composite was one of them. It was called the composite because of its design that integrated the Corinthian and ionic. While it adopted the acanthus leaves from the Corinthian order in the lower part of the capital, it adopted the spiral scrolls in the upper part. Almașry, Tarikh Alfan, p.189.; Bishay, Ibrahīm and Abdulmigīd, Tarikh althakhrafa, pp.304-305.

5 The Roman architecture utilized the styles of the Greek columns (the Tuscan, Dorique and ionic) and two other orders were added that were originally inspired by the previous three ones; the Corinthian was one of them and was introduced by Callimachus. The name "Corinthian" is derived from the ancient Greek city of Corinth. This order resembled the ionic one, but it exceeded the ionic in being more beautiful and the most widely used in the Roman buildings because the Roman people were lovers of greatness and greatness and splendor. Qadous, Tarikh 'am llfunon, pp.121-122; Almașry, Tarikh Alfan, p.188.

56 The so-called wooden cushions or tympanums architectural style was transferred from the Byzantine architecture to the Islamic one. Its oldest example is in the Mosque of Amr ibn al-As, Fustat (421A.H./642A.D.). Shaffī, Al'imara ala'rabia, pp.148-9; Nazīf, dirasat fĩ al'imara alislamīh, p.58; Rizq, Muajam Mustalahat Al'imara wa Alfonon alislamīh, p.191.

${ }^{57}$ They were widely used in the patand of the mosques' arcades in the $19^{\text {th }}$ century because of being affected by the Byzantine architecture. They were introduced for the first time in the Islamic architecture in Qubbat alSakhrah. In Egypt, they were introduced in the Mosque of al-hakim (380-403A.H./990-1013A.D.). Marzouq, Masajid alqahira, p.75.

${ }^{58}$ These stones were moulded in a good way forming flat and regular surfaces. The surfaces are often polished and the filings are always good and less thicker than the other parts of the buildings. The walls in which the stones are used, they are built inside and outside from moulded stones. They are used in the façades of some buildings that are known as the buildings of harmonized stones and of different sizes. Amīn et al., Fan albina',Vol.(1), pp.99-111.
}

- 188 - Hilal Bey Mosque in Kūm Al-nūr, Daqahlia (1270 A.H/ 1853 A.D) 
parts, there is a protruded course called 'qasas, 59 (Pl. 12) and topped with protruded stone frames. From the bottom-up, they are a concave of quarter of a circle form, a convex of a quarter of a circle ${ }^{60}$ form also, and a rib, respectively. The upper part of this wall and the other internal walls of the prayer hall are whitewashed yellow till the ceiling with height 4.76 meters. Flank the mihrab a recess on each side raises $60 \mathrm{~cm}$ in height above the ground level. The recess directly eastern the mihrab replaced the suggested window, and then plugged up. It is 1.19 meters in height, $77 \mathrm{~cm}$ across and $57 \mathrm{~cm}$ in depth. Additionally, the windows in both recesses are void of decorations. The other two lateral recesses flanking the mihrab raise $60 \mathrm{~cm}$ above the ground level, with dimensions 5.11 meters in height, 1.13 meters across, and $57 \mathrm{~cm}$ in depth. Each one of latter recesses contains three windows: the lower window has two modern wooden shutters, while the other windows described above in the southeastern façade (Fig. 19, Pl. 17).

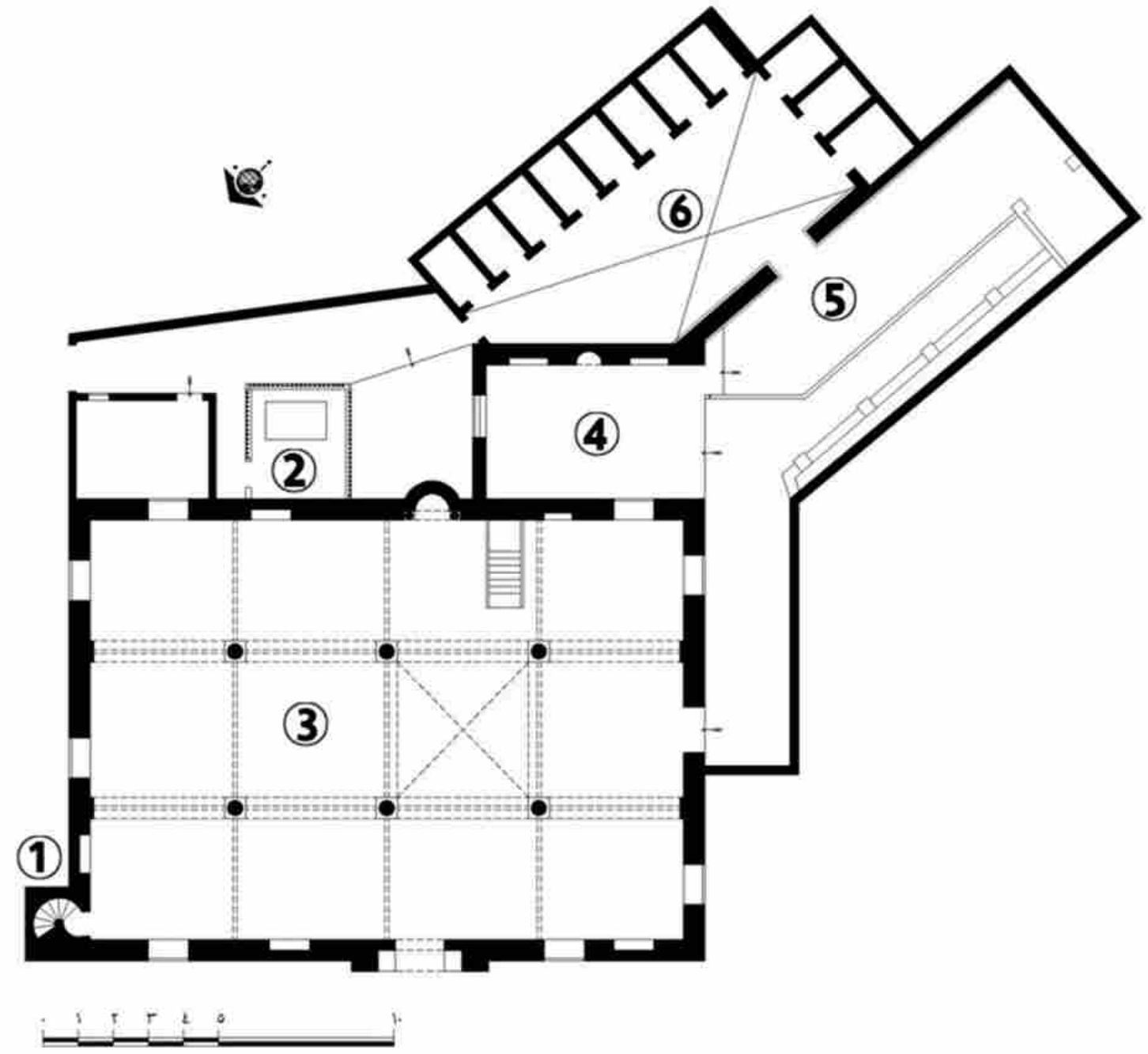

Fig. 16. A plan of Hilal Bey Mosque

\footnotetext{
${ }^{59}$ It is the raised part of any bond above the base of the building. It is about a quarter of a brick. The raised bonds are created to increase the horizontal area and the surface of the lower base in order to distribute the pressure on a larger surface. Additionally, they are created to enlarge the thickness of the wall to hold the different parts of the ceiling and to have an architectural shape of projecting brackets in different areas. Amīn et al., Fan albina',Vol.(1), pp. 65-66.

${ }^{60}$ It is a quarter of a circle. Amīn et al., Fan albina',Vol.(1), p.152
} 


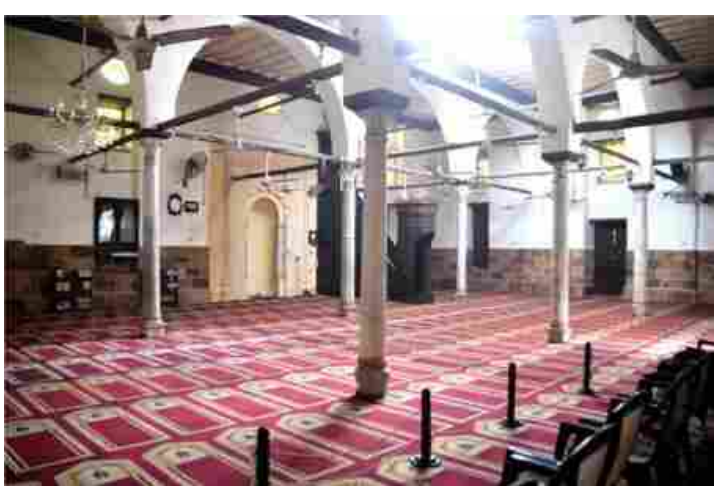

Pl. 12. The interior of Hilal Bey Mosque
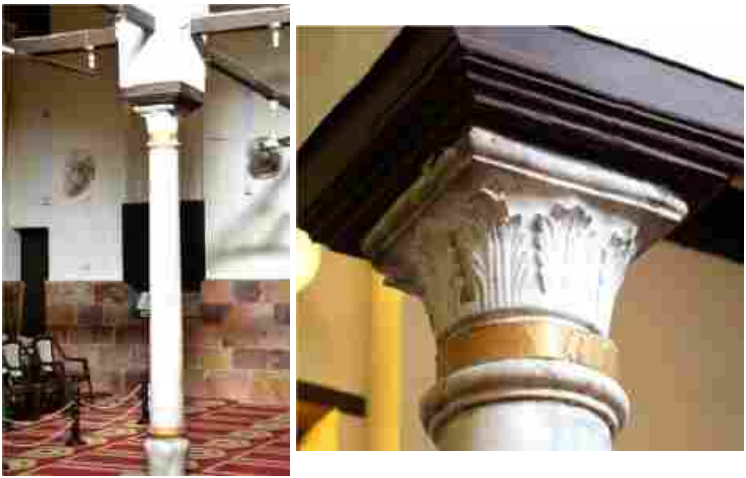

Pl. 15\&16. A column of the mid arcade \& its capital
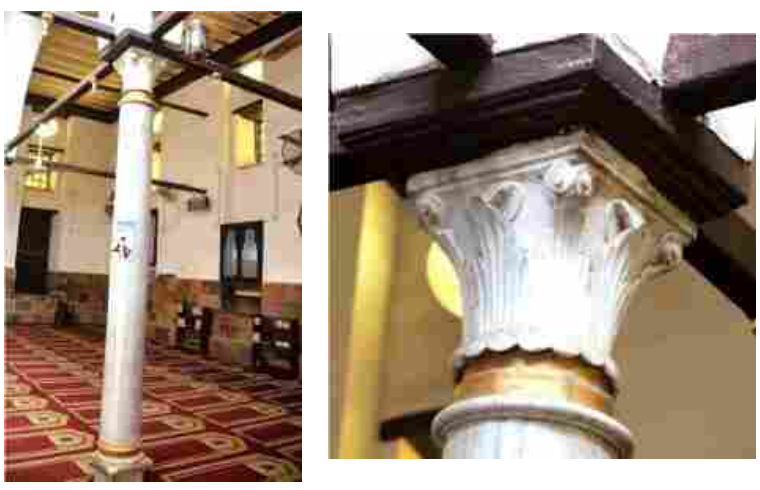

P1. 13 \&14. A column of the 1 st arcade next to the qibla wall $\&$ its capital

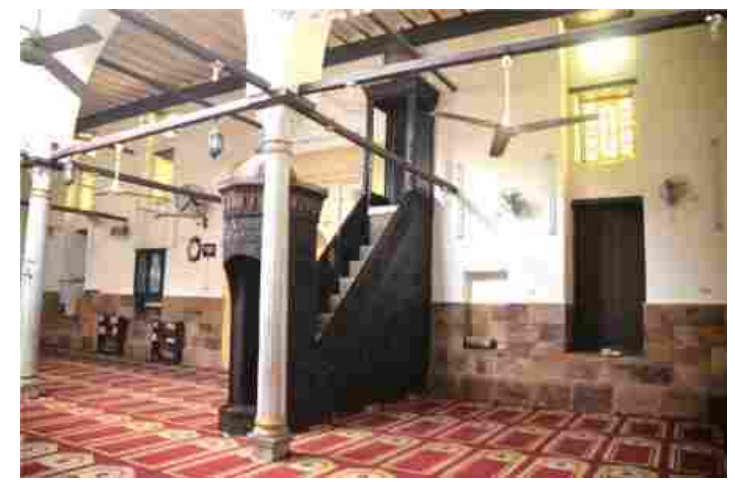

Pl. 17. The qibla wall of Hilal Bey Mosque

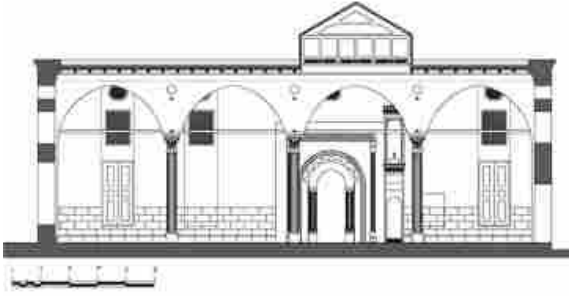

Fig.17. An interior section of Hilal Bey Mosque twoards the qibla wall

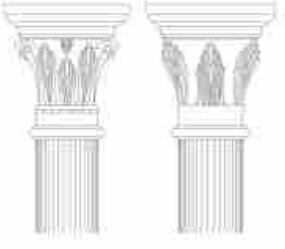

Fig.18. Capitals of columns

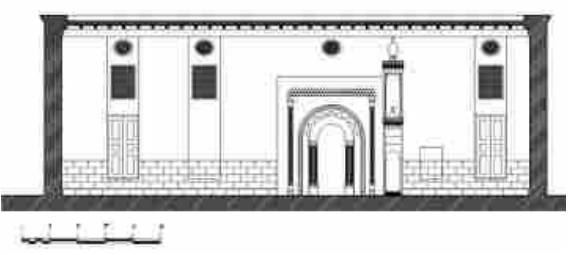

Fig. 19. The qibla wall of Hilal Bey Mosque

The Mihrab. The mihrab is located in the southern part of the qibla wall rather than the mid. The mihrab niche is placed within a large rectangular stone composition 4.28 meters in height and 3.80 meters in width. It protrudes about $10 \mathrm{~cm}$. In its upper part, there are two semi-protruded columns known as the lobe; each one consists of a base, shaft and capital. Their decorations are engraved in a high relief pattern. The base consists of much stone licentiousness, including the rib, semi-cane ornament, right concave quarter of oval (downup), respectively. It is decorated with equilateral triangles that are down and up interchangeably. Then, there is another stone licentiousness, known as quarter ${ }^{61}$ over bulging and it is decorated with zigzag pendentives ${ }^{62}$, followed by a stone licentiousness, known as

\footnotetext{
${ }^{61}$ It is a curve that equals a quarter of an ellipse. Amīn et al., Fan albina',Vol.(1), p.152.

${ }^{62}$ It is known as zigzag and pendentive. It takes the form of lines with acute angles like the blade of a saw. It was originally used in the Greek, Roman, Sassanid, Byzantine and ancient Egyptian arts. In Egypt, it was
}

- 190 - Hilal Bey Mosque in Kūm Al-nūr, Daqahlia (1270 A.H/ 1853 A.D) 
inverted wave decorated with acanthus leaves ${ }^{63}$ in an inverted way. After that, there is a stone licentiousness, known as semi-cane ornament. The body of each column is decorated with two parallel bands moulded with semi-circular cloves in an embossing pattern, enclosing a band of high relief pyramid forms. The capital of each column followed the Corinthian style and it is based on some stone licentiousness that are (down-up) the rib, semi-cane ornament and rib, respectively. Above the capital, there are also some stone licentiousness, as follows: the rib, concave quarter of a circle, rib, concave quarter of a circle and convex quarter of a circle. The two columns are separated by two moulding bands, enclosing a rectangular area void of decoration. The lower band consists of many ribbons; two parallel moulding ribbons decorated with semi-circular cloves and enclosing a ribbon of pyramid figures in an embossing pattern, while the upper one shows two stonelicentiousness: namely a concave quarter of a circle and convex quarter of a circle. In the middle of the large rectangular stone composition, there is a rectangular recess of 3 meters in height, 1.66 meters across and $5 \mathrm{~cm}$ in depth that is arched with a blind arcade ${ }^{64}$ of seven camel-neck arches. Beneath the end of the two arches at the end of the $8^{\text {th }}$ arcade, there are 8 oval figures on each side that are implemented in a high relief on the stone. Furthermore, the rectangular recess is enclosed in 3 moulding bands that extended to the lower part of the recess in a high relief pattern on stone. Inside-out, they are a semi-cane ornament, convex quarter of a circle and torsades that consists of two broken intersected lines, enclosing rhombuses. The spandrels of the rectangular recess and the surrounding area are decorated with recurrent geometric figures consisting of a hexagon that comprises 3 rhombuses engraved in a high relief pattern on stone. In this șadr, is the mihrab niche; with a semicircular plan crowned with a semi-circular arch. The mihrab niche is 2.44 meters in height, 1 meter across and $68 \mathrm{~cm}$ in depth. Its arch rests on two columns; each one consists of a stone base, cylinder shaft of onyx marble and its enclosed, in the upper and lower parts, with brass collar that is decorated with copper licentiousness, namely the semi-cane ornament in

introduced in the inner part of Bab an-nașr (480H/1092A.D.), then in Borj Elzofr in Cairo Citadel (572H./1176A.D.). In the Mamluk era, this ornament was used in the arch of the northeastern entrance of $\mathrm{Al}$ Zahir Baibars Al Bunduqdari Mosque (667a.H./1269A.D.). Shaffī, Al'imara ala'rabia, p. 95; Hasan, alhiliat alzokhrofia 'la 'ma'ir alqahira, pp.110-111.

${ }^{63}$ Acanthus leaf is large and pointed and it grows in stone. It was known in Egypt a long time ago. In the $2^{\text {nd }}$ half of the $5^{\text {th }}$ century, Lotus was modified with this plant which led to have acanthus as an independent ornamental unit. It is thought that, artists and decorators did not initially copy the plant as is in nature, but they tried palmettes that were similar to acanthus. In addition, acanthus was the most widely used floral ornaments in the Coptic art that also moved to the Islamic one. It was also found in the Hellenistic period. Bishay, Ibrahīm and Abdulmigīd, Tarikh althakhrafa, pp.251-270; Alshal, Muștalahat fi alfan waltarbya alfania, p.111; Yusif, Dirasa atharia lil-anasir alzokhrufia wa-lasalīb asinsi, p.142; Alshahawy, Ba 'd Mazahir Alta'thirat Albizantia, pp.80-81; Yusif, ashgh'l alurkham fĩ q'ṣr alamīr Mehmed 'alī, pp.362-364.

${ }^{64}$ It is an element that was originally Sassanid. It was introduced to the Ummayad architecture in the desert of the Levant and was also used in the decoration of the early Islamic metal antiques, e.g. a bronze pot that dated back to the Umayyad caliph Marwan bin Mehmed (2H./8A.D. century). It was also used in the decoration of wooden artifacts in Egypt in the $3^{\text {rd }}$ and $4^{\text {th }}$ Hijri (9-10A.D.) centuries. It continued into theFatimid period, for example in the inner part of the Caliph al-hafiz's dome in the northern end of the transept of Al-Azhar mosque 544a.H. (1149A.D.). After that, it moved to the Mamluk era when it was used in the decoration of the apron and the mihrab of the shrine of Sultan Qalawūn 683-684a.H. (1284-1285A.D.). This mihrab was the first in which this element was used in its decoration in Egypt. Then, it continued to be used in the Ottoman period. Omara, Al'anasir alzokhrofia, p.35. 
addition to a Tuscan or a Doric capital. ${ }^{65}$ Above the mihrab, there is an oval small window covered with modern metal wires (Fig. 20, Pl. 18).
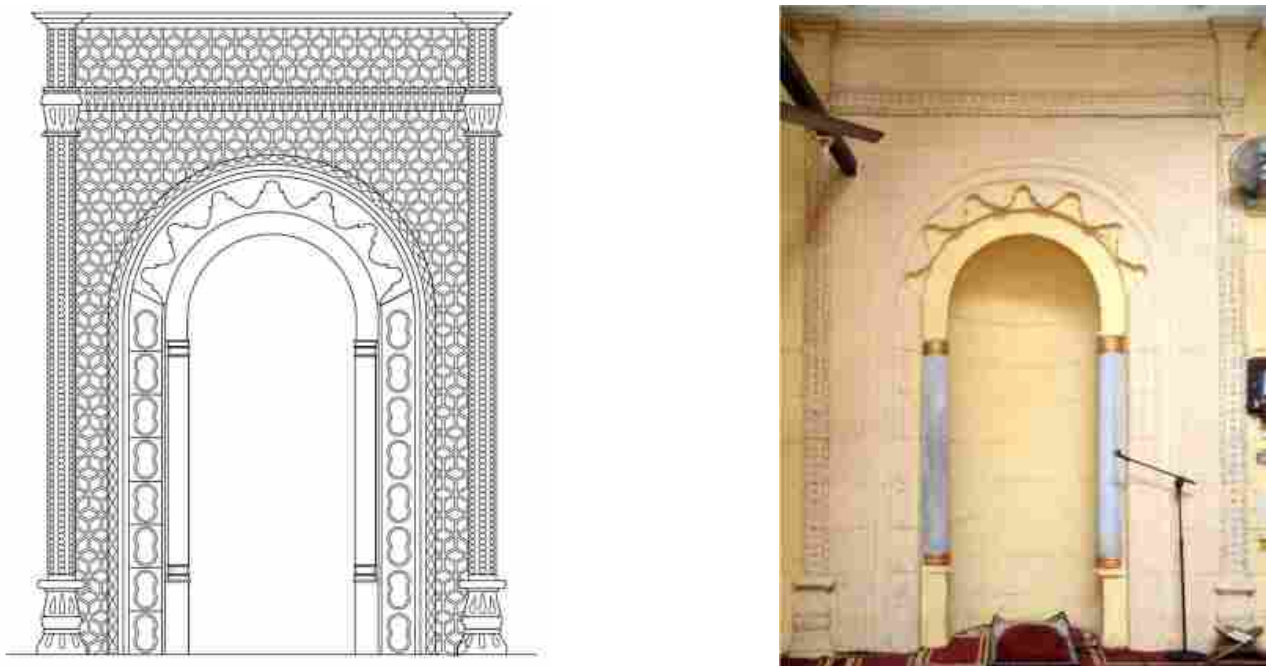

Fig. 20 \& P1. 18. The mihrab of Hilal Bey Mosque

The Minbar. ${ }^{66}$ It is placed direct southern the mihrab. It is a wooden made of Oak and Beech. ${ }^{67}$ It has a wooden rectangular base adorned with geometric figures engraved in a high relief pattern and the polygon interchangeably, enclosing quadrilateral geometric forms. The minbar consists of a frontal panel, a risha, a seat, two shutters and the djawsaq (Fig. 21).

The frontal panel has the minbar's entrance; it is an arched opening crowned with a keel arch, and each spandrel is adorned with a crescent containing a polygon. ${ }^{68}$ It is closed with four shutters with similar decorations. Each shutter is divided into four decorative areas: 1) the lower area contains rectangular pieces void of decorations, 2) the second area is decorated with turning and hexagon mofawaq surrounded by angels, 3) The third area is the

\footnotetext{
${ }^{65}$ The Tuscan order was named after Tuscany, Italy, but historians claimed that it was transferred from Etruria, Anatolia. The authors of the Renaissance period known it from the Roman building because it was preferred in the construction of many palaces for its simplicity and elegance. For example, it was employed in the northern entrances of Palace of Ismael Sedeek 1286A.H. (1869A.D.) in Lazoghly square; before each entrance, there are two columns of the Tuscan order. Almașry, Tarikh Alfan, p.186; Nigm, Altoroz alm'maria walfania, pp.320:321.

${ }^{6}$ Taman elaborated the description of the pulpit of Hilal Bey Mosque. Taman, Almanabir Albaqia fi Shark Aldelta, pp.36:38.

${ }^{67}$ Beech is a type of wood that is imported by Egypt. It often grows in the northern temperate region of Europe, Asia and North America, such as Armenia and Anatolia. It largely grows in the European mountains, e.g. the Alps. It is a flexible wood and has several forms, such as the red and white that are both used in the various woodworks. Kishk, Ashghal alkhashab fi al'amair al'othmania, p.79.

${ }^{68}$ The crescent is a lunar phase that refers to the moon. It has a religious significance for the Muslims. Therefore, it is noted that it is mentioned in the Holy Qur'an. For example, (they ask you, [O Mehmed], about the new moons. Say, "They are measurements of time for the people and for hajj" (1:189). For the Muslims, it refers to the beginning of the Hijri month and indicates the times of prayers and hajj. The polygonal knotworks were used to refer to the goddess Nut in the ancient Egyptian religion, while they represent the perfect man in the Greek philosophy. The oldest Islamic building that was decorated with these two elements was Rock Dome in which the inner part of the middle octagon arcade was decorated with a crescent enclosing a hexagonal star and surrounded by eight polygonal knotworks. Another scene was observed in a corner of the Kaaba that contained a star. In Egypt, their oldest example was found in the remaining buildings of the apex of the mihrab's arch in Alhakem Mosque (380-403A.H./990-1013A.D.). Zaki, Al'alam almișry, p.11; Nigm, dirasa hawl almadlolat alfalakia waldinia, pp.88-89; Nigm, Shi'ar alothmanin 'la ala'ma'ir walfunon, p.179; Creswell, The Muslim Architecture of Egypt, p.231; Yasīn, Alramzyh aldinyh fĩ alzkhrafh alislamīh, p.60.
}

- 192 - Hilal Bey Mosque in Kūm Al-nūr, Daqahlia (1270 A.H/ 1853 A.D) 
largest takes the form of a rectangle and contains polygons of 8 kendas ${ }^{69}$ and the polygons are separated by pentagrams, as well as quadrilateral and pentagonal geometric figures implemented in interlacing form, 4) and the upper 'fourth' area is decorated with a turning of a complete cross. Above the arch of the frontal panel, there is a moulding band similar to that of the base of the minbar. It is decorated with polygons in the upper and lower parts, as well as hexagonal and quadrilateral geometric figures separated by hexagonal star. Above this band, there is a cornice of two rows of stalactites of parabolic arches with pendants, upon which there is a row of windows in the form of pentagonal leaves on a base of arcade with keel arches. The djawsaq is crowned with a semi-circular hood voided of decorations. Above the dome, there is the figure of a bird. Both side of the minbar's frontal door are similar in decoration; each section is divided into five decorative areas, among which the largest is the middle one, which is a rectangular area decorated with a 10 -kendas polygon. ${ }^{70}$ The polygon is enclosed with pentagonal stars and quadrilateral figures. In the upper and lower parts of the aforementioned polygon there are two inversed halves of polygon, each half has 6 kendas, and enclosed with four pentagonal stars that separate it from the full polygon. In addition, the upper and lower halves of the polygon, there is a half polygon of 5 kendas. While the $1^{\text {st }}$ and $5^{\text {th }}$ areas of both sides are decorated in turning figure of small balusters, the $2^{\text {nd }}$ and $4^{\text {th }}$ areas are square and are decorated with the turning of hexagonal almofawaq ${ }^{71}$ (Fig.no.22).
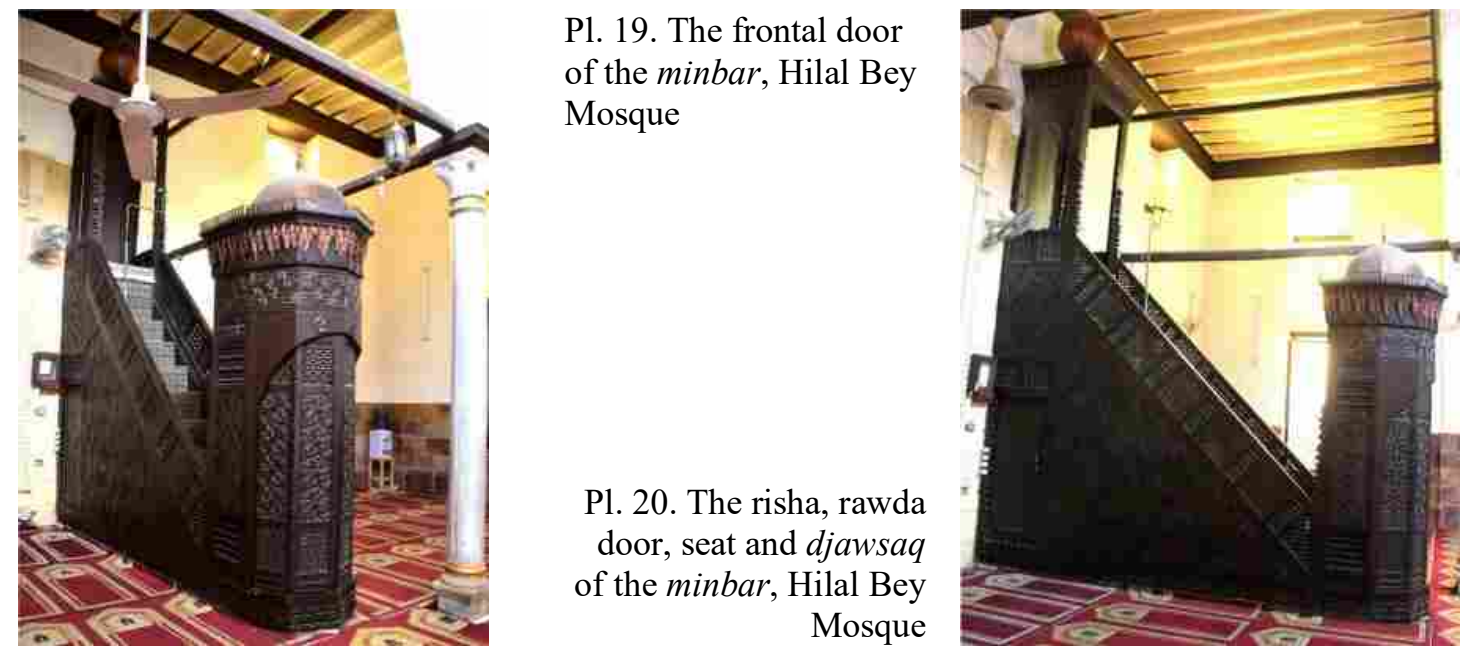

The minbar sides 'risha'. Both are right angled-triangle form, with interlaced geometric decorations. Each side 'risha' comprised 3 polygons of 16 kendas in the center, surrounded by pentagonal star patterns interchanged with the so-called house-crow. This composition is encircled by 9 halves of polygons; each one among which has 9 kendas. Moreover, each side 'risha' has a quarter of polygon of 3 kendas, and the complete and the halves polygons are separated by 10 ornamental units that take the form of octagons surrounded by 4 hexagons and separated by 4 quadrilateral stars. In the balustrade of the minbar, there are various types of balustrade. It is divided into 13 ornamental panels and 6 triangular panels of the sides are

\footnotetext{
${ }^{69}$ The oldest wooden example that was decorated with this element is the risha of the Al-aqsa Mosque's minbar (564A.H./1169A.D.) Kishk, Ashghal alkhashab fi al'amair al'othmania, p.139.

${ }^{70}$ Its oldest example is the frontal panel of Alsaleh Mosque 555A.H./1160 A.D. Kishk, Ashghal alkhashab fi al'amair al'othmania, p.141.

${ }^{71}$ It is a hexagonal turning form with tripartite units connected with small turning units. Kishk, Ashghal alkhashab fi al'amair al'othmania, p.415.
} 
decorated with alkhart almaymouny almoraba' and altemsah alqae'ma. This is formed by the turning of octagonal patterns with oval handles. The $4^{\text {th }}, 3^{\text {rd }}, 7^{\text {th }}$ and $11^{\text {th }}$ panels are filled with hexagon almofawaq turning and surrounded with triangles, while the $5^{\text {th }}$ and $9^{\text {th }}$ ones are filled with complete crosswise turning (Fig. 23).

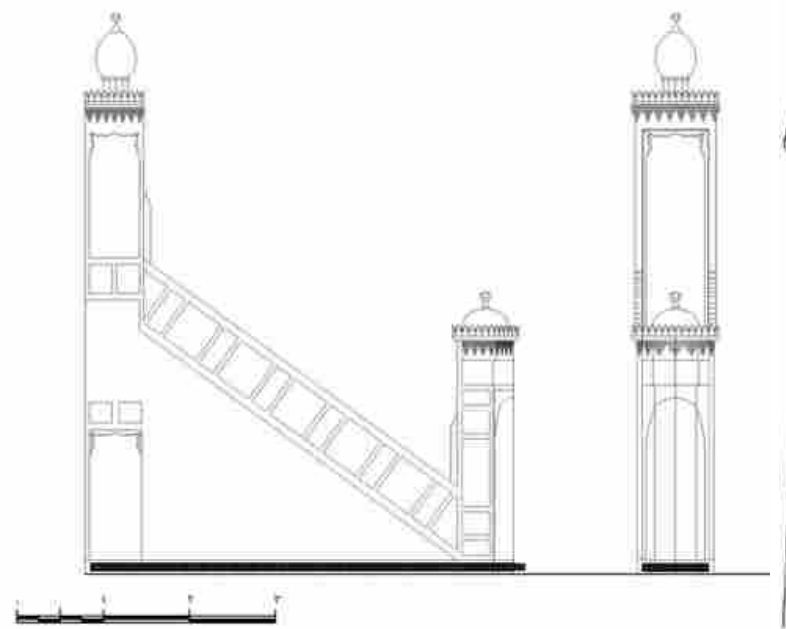

Fig. 21. The minbar of Hilal Bey Mosque
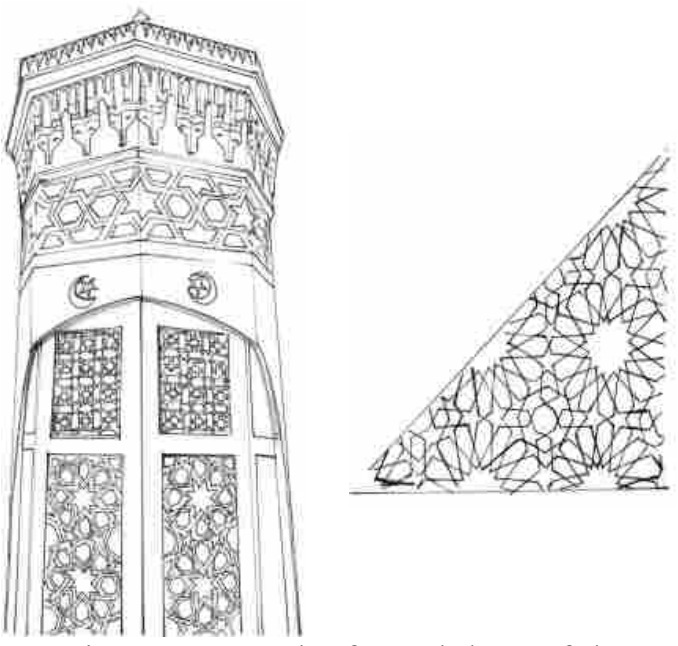

Fig. $22 \& 23$. The frontal door of the minbar \& the risha

The shutters. They placed at the end of the sides of the minber 'risha' and each of them is $\mathrm{s}$ urrounded by serrated decorations and semi-circular figures implemented in cutting and pierc ing. They are closed by two wooden shutters void of decorations and above them, there are $t$ wo panels filled with octagonal turning with oval handles. Above the shutters from the two si des, there is a rectangular area of a full polygon of 10 kendas surrounded with a quarter of po lygon of 3 kendas in the four corners. They are implemented in the additive panels practice.

Seat. It is a square wooden sitting accessed by 8 steps void of decoration. It has two sides that each of which has 2 square panels of the fine crosswise turning.

The djawsaq. It consists of 4 cross-sectional pillars, enclosing 3 openings that are decorated with chevron decorations from the upper and lower parts similar two those around the shutters. The $4^{\text {th }}$ side is the back of the seat that takes the form of a horse-shoe arch. The djawsaq is crowned with a cornice of two rows of stalactites of parabolic arches with pendants and each row is crowned with a row of small windows, taking the form of a triple leaf. Above the djawsaq, there is an onion-form dome above which there is a pillar of 3 spherical bulges with a bird figure at the top.

The northwestern wall. In its mid is the entrance of the prayer hall. The entrance dimensions are 5.71 meters in height, 1.42 meters across and $50 \mathrm{~cm}$ in depth. Two recesses flank the entrance, each one raises $60 \mathrm{~cm}$ from the ground level, and it is 5.11 meters in height, 1.13 meters across and $57 \mathrm{~cm}$ in depth. Moreover, it contains 3 windows, except for the one northern the entrance that contains only 2 windows. The lower window in both recesses is closed with modern wooden shutters, but the other windows as were described above in the northwest facade (Fig. 24, Pl. 21).

The southwestern wall. In the middle of the southwest side, the entrance of the mosque exists. Its entrance dimensions are 5.71 meters in height, 1.30 meters across and $57 \mathrm{~cm}$ in depth. Flanks the entrance a recess on each side has the same above measurements of the

- 194 - Hilal Bey Mosque in Kūm Al-nūr, Daqahlia (1270 A.H/ 1853 A.D) 
recesses of the NW wall. Additionally, it contains 3 windows. The lower window in every recess is closed with two modern wooden shutters, while the other windows as those described in the NW façade (Fig. 25, Pl. 22).

The northeastern wall. It contains 3 recesses that raise $60 \mathrm{~cm}$ from the ground level. Each one is 5.11 meters in height, 1.13 meters across and $57 \mathrm{~cm}$ in depth, and contains 3 windows. The lower window in all recesses is internally closed with modern wooden shutters, while the other windows as were described in the northeast façade (Fig. 26, Pl. 23).
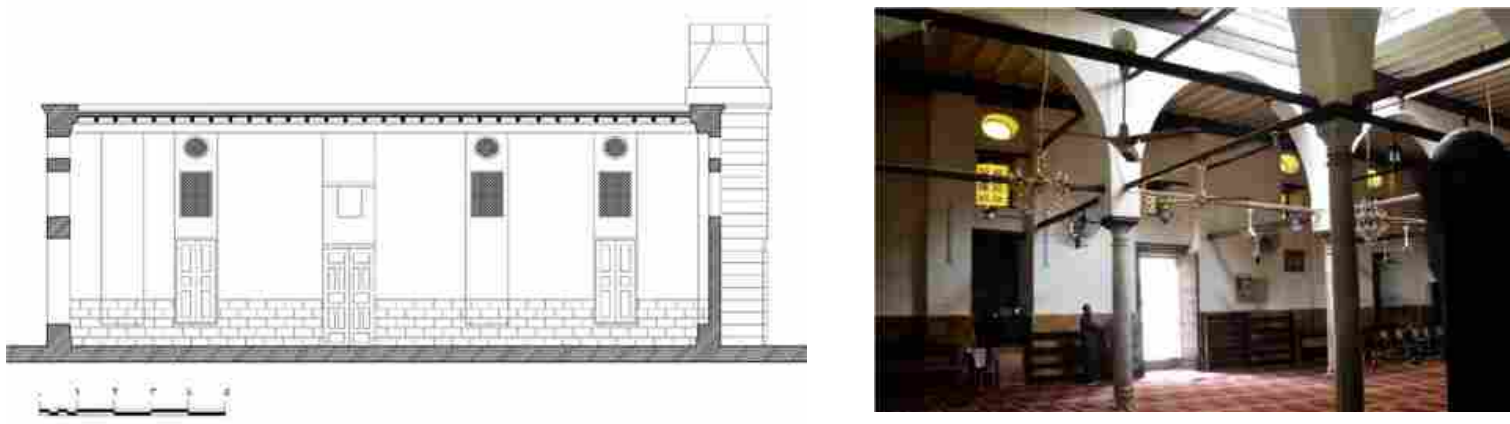

Fig. $24 \&$ P1. 21. The NW wall of the prayer hall of Hilal Bey Mosque
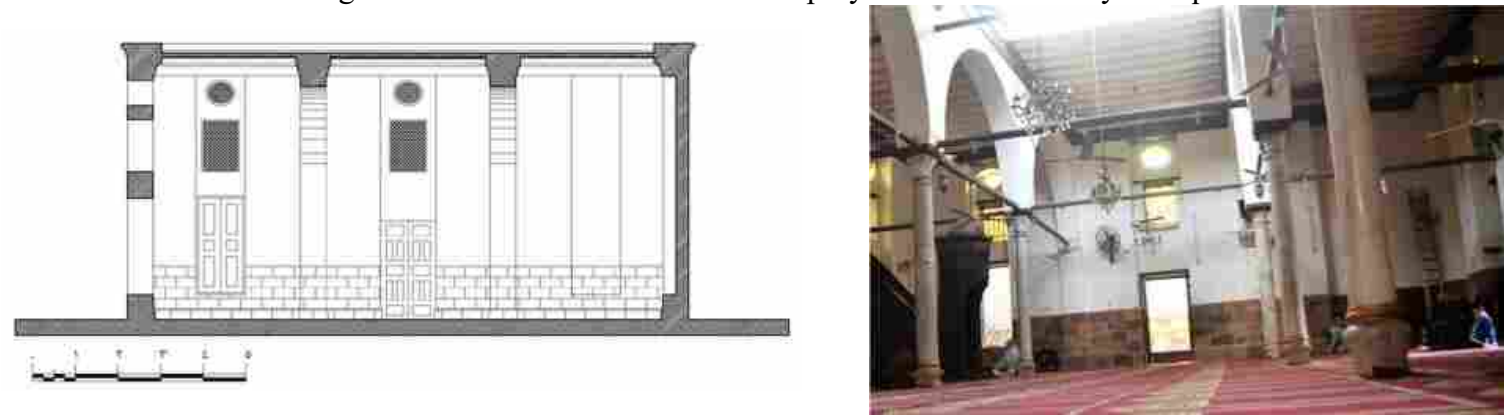

Fig. $25 \&$ Pl. 22. The SW wall of the prayer hall of Hilal Bey Mosque
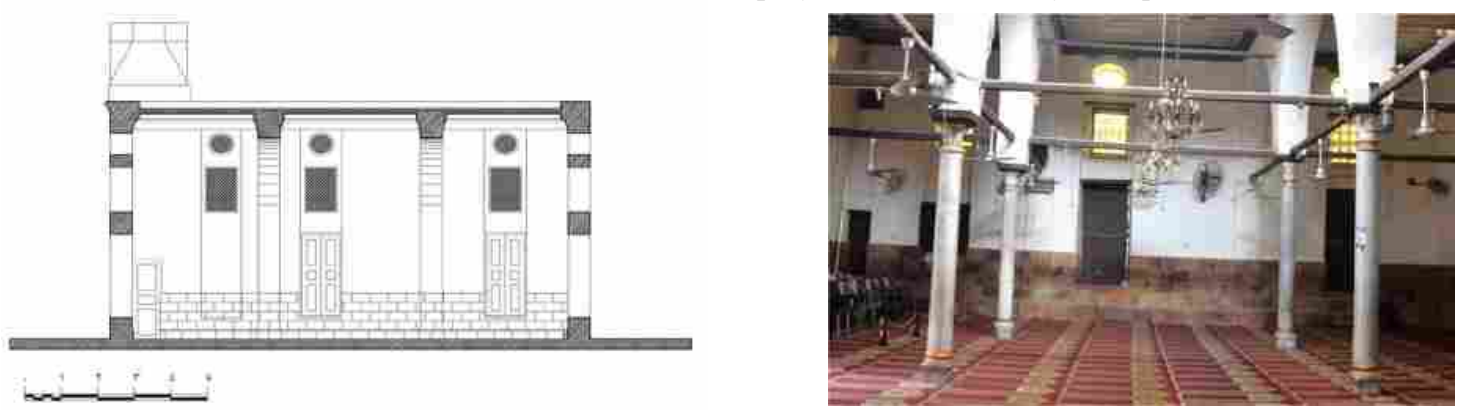

Fig. $26 \&$ P1. 23. The NE wall of the prayer hall of Hilal Bey Mosque

Floors and Ceilings. The floor is covered with modern ceramic tiles, while the ceiling is made of wood on wooden braces ${ }^{72}$ (pl. 24). The two ends of each brace are decorated with a rectangle wooden panel executed in piercing; ending with an arrow's head form beneath two reverse crescents separated by a rhombus. Above these two crescents, there are two

\footnotetext{
${ }^{72}$ They are the wooden blocks that cover the ceiling. The runner is from $(4.60 \mathrm{~m})$ to $(13.80 \mathrm{~m})$ long. It is placed longitudinally and horizontally and the wooden panels are put above it. In addition, it is decorated with floral and geometric ornaments and painted with various colors and it is sometimes polished with gold and lazord. It often consists of many parts, including the naal that takes a (nearly) square section and the middle part that is named as seaha and it is often circular and rectangular section. Between every two runners, there are square and rectangular socles. Abdulhafiz, Almoṣtalahat alm 'maria, p. 30.
} 
rhombuses, followed by a crescent, then a rhombus, respectively, then atop a wooden upright (Fig. 27, P1. 25). There is a rectangular wooden lantern ${ }^{73}$ covers the mid of the middle aisle of the prayer hall. It is measures 4 meters in length, 3.10 meters in width and 1 meter in height; atop which is a pyramidal wooden ceiling of $85 \mathrm{~cm}$ in height. In each one of both longitudinal sides of the lantern open eight similar windows closed with glass; each one is surrounded by a wooden frame that takes the form of a segmental arch. However, in each one of both short sides, open six similar windows $(65 \mathrm{~cm}$ in height, $41 \mathrm{~cm}$ across), closed by glass, within a wooden frame crowned with a depressed arch. Below each side of the lantern, there are three rectangular areas that are decorated with embossing wood frets. Additionally, each side of the rectangular ceiling is decorated with geometric patterns of wooden pieces 'sadaieb'. ${ }^{74}$ This shape consists of two parts form together an equilateral triangle (Fig. 28, Pl. 26). The first part is a rectangular figure; its short sides with cut-off corners, and the angles of the rectangle formed as arrows' heads. While the second 'upper' part is an equilateral triangle; which its base resembles an arrows' heads as well.

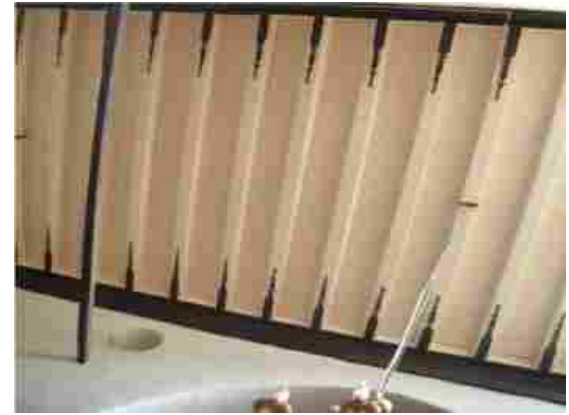

Pl. 24. The ceiling wooden braces, Hilal Mosque
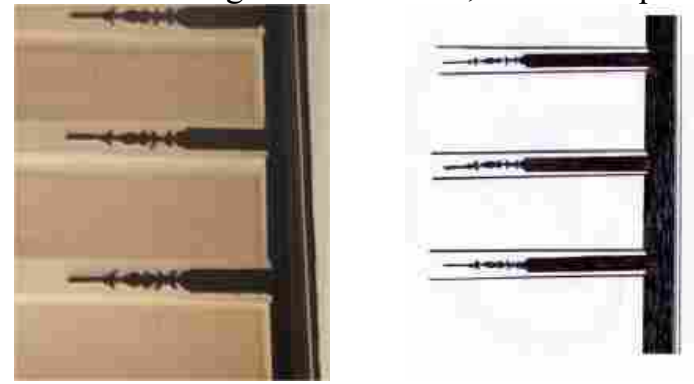

Fig. $27 \&$ Pl. 25. Detail of the decorations of the wooden braces of the ceiling of Hilal Bey Mosque
P1. 26. The lantern of Hilal Bey Mosque's ceiling

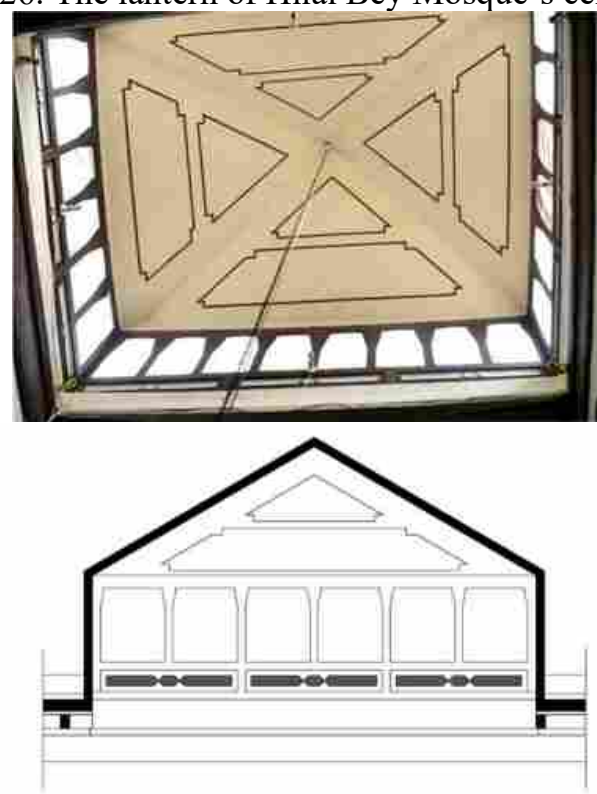

Fig. $28 \&$ P1. 26. The lantern of the ceiling of Hilal Bey Mosque: A photo \& a section

The Oratory 'Almusalla' ${ }^{75}$ It is next to the southeastern façade of the mosque. It is an iwan with a rectangular plan of 6.20 meters in length, 3.79 meters across and 3.40 meters in height. It opens completely by its southwestern façade overlooking the ablution fountain. In the mid of the southeast wall of the musalla the mihrab is placed; a semi-circular niche of $81 \mathrm{~cm}$ across, $35 \mathrm{~cm}$ in depth and 2.35 meters in height. Its arched hood is adorned with ray

\footnotetext{
${ }^{73}$ Linguistically, it means the sound of weapon, paper..etc. Architecturally, it is the skylight raised from the ceiling of the room, corridor or stairs. It often takes the form of a wooden polygon or octagon with wooden veils and glass windows. Abdulhafiz, Almoṣtalahat alm 'maria, p. 116.

${ }^{74}$ They represent an industrial method in decoration with sadaeeb and raised frames that are fixed on the wooden ceiling. They are either singular or dual. Kishk, Ashghal alkhashab fi al'amair al'othmania, p. 412.

${ }^{75}$ Attaching musallas to the buildings was familiar in Egypt, e.g. to the cemetery of Emetsh Elbejashy in Bab Elwazir 785A.H./1383 A.D. Additionally, they were attached to some Ottoman public drinkings in Cairo, e.g. to the public drinking of Muștafa Sinan in Souq al-silạ̣ (1040A.H./1630.D.). Najīb, Madrasit Khayrbak bi-bab Elwazir, p.35; Alhussiny, Al'asbila alothmania albaqia bimadinat alqahira, 1982, p.408.
} 
lines ${ }^{76}$ in intaglio pattern on plaster. The mihrab has been recently painted with oil. There is a rectangular recess flanks the mihrab on each side, used as a bookstore. It raises $60 \mathrm{~cm}$ from the ground level, and its dimensions are 2.26 meters in height, 1 meter across and $30 \mathrm{~cm}$ in depth. Furthermore, in the northeastern wall of the musalla, there is a rectangular recess with the same aforementioned dimensions; in which is a rectangular window of 1.69 meters in height and 1 meter across. The floor is covered with modern ceramic tiles, while the ceiling is covered with wood on wooden braces (Figs. 16, 29, Pls. 27, 28).

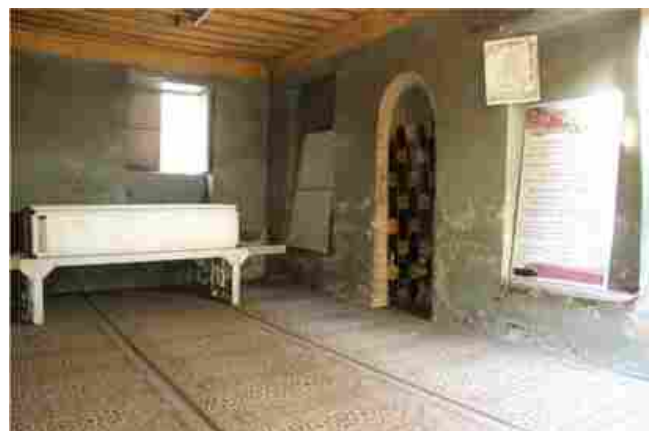

Pl. 27. The musalla of Hilal Bey Mosque
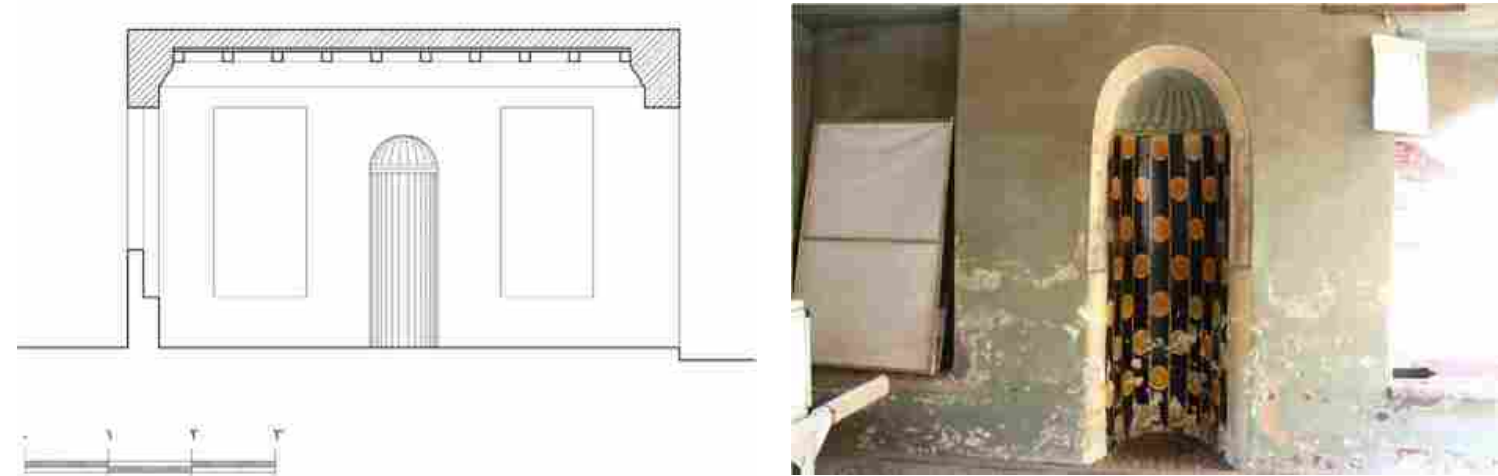

Fig. $29 \&$ Pl. 28. The SE wall of the musalla of Hilal Bey Mosque

The ablution fountain and latrines. The ablution fountain or lavatory occupies the northern part and the latrines in the southern one. The south-east wall (measures 6.78 meters length and 2 meters in height) of the lavatory separates the lavatory and the latrines. A rectangular opening door ( 2 meters in length and 1.26 meters across) centers the aforementioned wall. In front of the lavatory is an open rectangular corridor (11.37 meters in length and 3 meters in width). It has a rectangular plan of (12.64 meters in length and 2.41 meters in width) and its wall measure 2 meters in height. In front of the northwestern wall, there is a rectangular brick basin measures 12.64 meters in length, $50 \mathrm{~cm}$ in width and $30 \mathrm{~cm}$ in depth. Above this basin, small brick seats were built, facing the water taps. The lavatory is covered with a wooden ceiling based on 6 wooden braces, formed of sanboksat ${ }^{77}$ (Figs. 16, 30).

\footnotetext{
${ }^{76}$ Ray lines were utilized in the mihrab of Sayyidah Ruqayyah Mosque (527A.H./1133A.D.). Rays emanate from a small window in the middle that contains Kufic calligraphy of the word of "Allah"and ends with 3 rows of salactites that are gradually wider (in-out). This is also the case of the decorations in the mihrab of the southwest side in the lower part of this mosque. Hasan, Almaharib fi miṣr fi ala ș̣r alothmany wa a ș̣r Mehmed 'alī, p.203.

${ }^{77}$ It is known as the bearing knee and angle. It is either inscriptions or piercings in the form of triangles that are placed above the entrance of the building, doors and windows. It consists of a flat part and an eaves. Fahmy, Fahmy, almața' alquom ria fi Alabnya Alaskria, 1868,pp32-33; I'ssa, Mostalahat alfan alislami, p.31.
} 
The latrines are fronted by an open rectangular corridor measuring 10.80 meters in length and 4.36 meters in width. There are 11 latrines in the mosque taking the ' $\mathrm{L}$ ' form. Its southeastern side comprises 8 latrines; each one has a rectangular plan measures 1.83 meters in length, 1.14 meters in width and 3 meters in height, with a rectangular opening door (2 meters in length and $68 \mathrm{~cm}$ across) closed by a wooden shutter. Above the door, there is a rectangular window (1.14 meters in height and $50 \mathrm{~cm}$ across). The latrines' southwestern side comprises 3 restrooms as the above-mentioned ones (Figs. 16, 5) except of their width which is 1.49 meters.

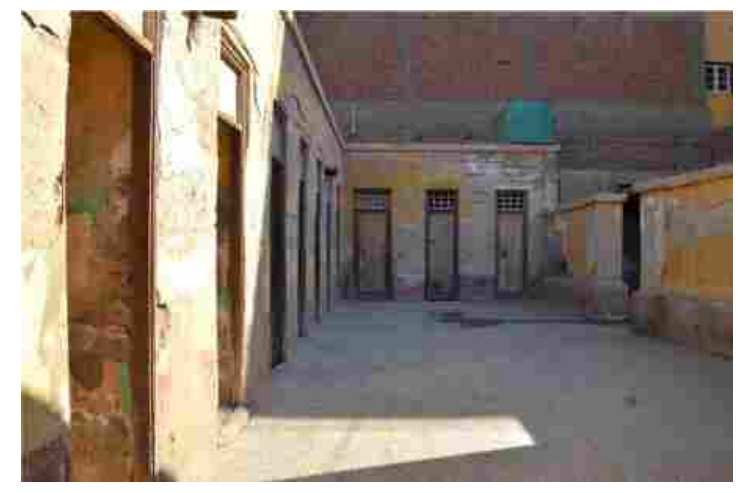

P1.no.29: The latrines of Hilal Bey Mosque

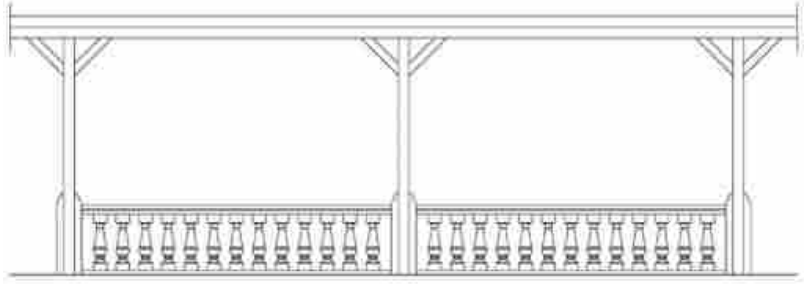

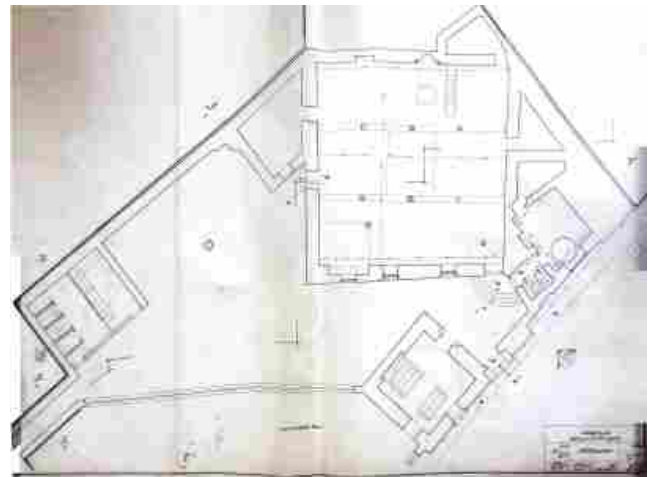

Fig.no.31: A projection of Ḥasan Paşa Ṭahir Mosque (Islamic and Coptic Monuemts Record Center- Ministry of Antiquities)

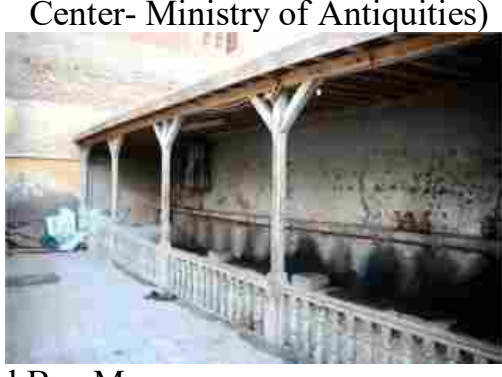

Fig. 30 \& Pl. 30. The lavatory of Hilal Bey Mosque

\section{ANALYSIS}

Plan. Hilal Bey Mosque follows the plan that so-called the aisles without a courtyard; a local Egyptian style ${ }^{78}$ that dominated, especially outside the Capital, during the Ottoman era onwards till the end of the $13^{\text {th }}$ A.H/ $19^{\text {th }}$ A.D. century. It consists of a rectangular area divided into aisles by a number of arcades and they differed from one mosque to another. These arcades comprise rows of columns topped by arches parallel to the qibla wall and topped by the ceiling. There were various examples for this plan in Cairo in the $19^{\text {th }}$ century, among which are 'bī Dar' Mosque of Bab Alkhalq (1217-1218H./1801-1802A.D.), Hassan Paşa Țahir Mosque in Birkat al-fil St. (1224 A.H./1810A.D.) (Fig.no.31) and Sulīyman Paşa al-faransawī Mosque ${ }^{79}$ Kūrnīsh Al-nīl St. (1276 A.H./1859A.D.). It was also known in the Egyptian Delta in the $19^{\text {th }}$ century, including al 'Abassī Mosque ${ }^{80}$ at Rosetta $\left(1^{\text {st }}\right.$ half of the

\footnotetext{
${ }^{78}$ The Egyptian (local) style: Hilal Bik Mosque follows the Egyptian local style that takes many forms. For example, porticos without court planning that comprises a rectangular space divided into three courts with three arcades parallel to the qibla wall. This form was introduced in Egypt in the era of 'umar bin al-khattab, e.g. in 'mr bin al-' as mosque in its early stages (21A.H./641A.D.). Sant Katrīn mosque (429-433A.H./1037-1041A.D. or 495-500A.H./1101-1106A.D.) is its oldest examples in Egypt. Alhadad, Bohoth wadirasat fi al'imara alislamīh, pp.272-281,167:188.

79 - hajaj, Altoraz alm 'mary walfany limasajid alqahira, ,p.11,20,113.

${ }^{80}$-Darwīsh, 'ma'r Rashīd wama biha min Tuhaf Khashabia, p.135.
} 
$13^{\text {th }}$ A.H/ $19^{\text {th }}$ A.D), 'Abdurahīm Mosque at Tanța-Gharbia (1229A.H/ 1813A.D), al- 'Adawī Mosque at Samanoud-Gharbia (1265A.H/ 1848A.D.), 'Aisha and hassiba Mosque ${ }^{81}$ at Sarsamūs village- Munūfia (1292 A.H./ 1875 A.D.), Manșur Qbaudin Mosque at Abūshusha St. in Alexandria (1252 A.H./ 1836A.D.) and 'lì al-mașrī Mosque ${ }^{82}$ at al-bab al-'khḍar- in Alexandria (1275 A.H. / 1858A.D.).

Building Materials. Different building materials were used for the construction of Hilal Bey Mosque, such as stone in the walls, bricks in the minaret, marble in the columns and the foundation inscription, as well as wood in the doors, windows, minbar, ceiling, lantern and glass in the lantern. Stone was used in building the walls of many mosques in Cairo in the $19^{\text {th }}$ century, as in Raḍwan Bey 'bi ashawarīb that also known as Mehmed Shirīf Paşa Mosque $^{83}$ in al-kirdasi St. (1277A.H/ 1859A.D), while limestone was used in the mosques of the Delta as found in Aḥmad Bey al-shirīf Zawia ${ }^{84}$ (1285A.H/1868A.D) at 'bīar village, Gharbia. Brick, though its advantage of resisting water and fire, was not widely used in the building of Cariene mosques during the $19^{\text {th }}$ century, especially if compared to stone. Marble columns were widely used in the $19^{\text {th }}$ century mosques of Cairo, including the Imam Shafi' $\overline{1}$ Mosque in Qarafit Imam Shafi'ī (1303-1309H./ 1885-1890A.D.) and Mehmed 'lī Paşa Mosque ${ }^{85}$ at the Citadel (1244-1265A.H./ 1827-1848A.D.). Furthermore, marble was used for the foundation inscriptions in some mosques in Cairo at that time, as the case of alqabr al- țawīl Mosque, ${ }^{86}$ at al-baqarī St. (1285A.H./1867A.D.). Wood was also extensively used in the architecture of the $19^{\text {th }}$ century mosques of Cairo because it is known by its light weight and good heat insulation. Therefore, it was used in manufacturing all doors, windows, minbars and ceilings of the mosques of Cairo, as well as those of Upper and Lower Egypt in the $19^{\text {th }}$ century.

Façades. Hilal Bey Mosque has strong and solid façades result of using stone built pilasters that support the walls on the interior. These pilasters have rectangular elevation and increase holding the walls both vertically and horizontally. They resemble those of other mosques in Cairo at the same time, including al-shuhad' Mosque at An-nașr St. (1276-1277A.H/ 18591860A.D). Additionally, Hilal Bey Mosque has four façades like those of the Mehmed 'li Paşa Mosque. These façades end with protruded stone bands similar to those of the Suliyman Paşa al-faransawi $\overline{1}$ Mosque. The angles of the minaret's base take the form of quarter of a circle engraved in stone. Moreover, the corners of the minaret's base are cut-off in order to respect the road, as in the $19^{\text {th }}$ century mosque of Suliman 'gha al-silhdar ${ }^{87}$ at al-Muizz St. (1253-1255A.H./ 1836-1838A.D.) in Cairo; especially at the corner of the southwestern façade.

The Entrances. Due to their vital role, the architects paid great attention to the entrances of the mosques that reflected in both its architecture and decoration. Hilal Bey Mosque has two entrances like some mosques of Cairo in the $19^{\text {th }}$ century as in the Mosque of Hassan Paşa Tahir $^{88}$ and in the Delta there is the Mosque of al-Qadī Hussain ${ }^{89}$ at Samannoud-Gharbia (1285A.H/ 1867A.D). The main entrance is to the left of the northwestern façade. This pattern was found in the $19^{\text {th }}$ century mosques of Cairo as the entrance of the Mosque of

\footnotetext{
81 - Albațway, Al 'ma'r aldenia alislamia albaqia bil-dilta, p8,26,70.

${ }^{82}$ - Diqmaq, Almasajid albaqia fi aliskandaria, p110,184.

${ }^{83}$ - hajaj, Altoraz alm 'mary walfany limasajid alqahira, p.130.

84 Albațay, Al ma'r aldenia alislamia albaqia bil-dilta, pp46:56.

85 - hajaj, Altoraz alm 'mary walfany limasajid alqahira, pp224,71:94.

86 hajaj, Altoraz alm 'mary walfany limasajid alqahira, pp 179:180.

${ }^{87}$ - hajaj, Altoraz alm 'mary walfany limasajid alqahira, pp125,71-94,113,44:46

88 - hajaj, Altoraz alm 'mary walfany limasajid alqahira, pp20:24.

89 - Albațay, Al 'ma'r aldenia alislamia albaqia bil-dilta, pp37:45.
} 
Sulīman 'gha al-silhdar ${ }^{90}$, and in the Delta is the Idrīs Mosque ${ }^{91}$ at Idrīs St. out of Sulțan Hussinn St. at al-Manșura (1321A.H/ 1899A.D.). The main entrance of this mosque is a direct pivotal i.e. it is placed on the axis of the mihrab. This pattern found in many examples in the $19^{\text {th }}$ century mosques of Cairo as the case of the entrance of al-dawakhli Mosque $^{92}$ at aldawakhlī St. (1228A.H/ 1813A.D.) and in the Delta, in al-nūr Mosque ${ }^{93}$ at alțawīla village, Daqahlia (1286A.H/ 1868A.D.). The entrance of the northwestern façade of Hilal Bey Mosque is a monumental entrance. It was also found in Cairo in the $19^{\text {th }}$ century, as the northeastern entrance of Imam Shafi'i Mosque ${ }^{94}$ and in the Delta as the case of the entrance of Idrīs Mosque, ${ }^{95}$ Manșura. Additionally, this entrance has two seats 'maksalas' as those of the northeastern entrance of Imam Shafi'i Mosque in Cairo and the northeastern façade of the Great Mosque $^{96}$ on Mansī St. at Bilbīs-Sharqia (1277 A.H/1860A.D). Furthermore, the portal of the Hilal Bey Mosque is arched with a stalactite triangular arch, and its apex is decorated with ray decorations. The pattern is common in the $19^{\text {th }}$ century mosques of Cairo such as the three entrances of the Shīkh Salih Abū hadid Mosque at Shīkh Salih al-hanafy St. at Saīda Zainab (1279-1280H./ 1862-1863 A.D.). The second entrance of Hilal Bey Mosque opens in the mid of the southwestern façade; it is a lateral direct one i.e. leads to the interior of the prayer hall directly but it is not on the axis of the mihrab. The same pattern is found in the Hassan Bey Ṭahir Mosque in Cairo and al-Qadī Hussain at Samannoud-Delta.

Windows. They were mainly functioned to provide the interior of the prayer hall with light and as possible and when there was a need. Windows, as well as in most mosques in Cairo during the $19^{\text {th }}$ century, are rectangular in the thickness of the walls closed by gratings and/or wooden shutters. The windows of al- 'hmar Mosque, 'ttaba (1264A.H/ 1847A.D) and Mehmed Bey al-madbul Mosque ${ }^{97}$ al-madbulī St. (1292 A.H/ 1874 A.D) present a good example of such windows. The windows of Hilal Bey Mosque that arched with relieving arches, closed by iron gratings are similar to those of the façades of Șalih Abu hadid Mosque, and they are closed also with two wooden shutters as in most Cairo mosques during the $19^{\text {th }}$ century.

There are different types and forms of windows with, sometimes, different functions. The upper windows of the facades of the mosques are usually smaller than the lower windows as the case of the mosque under discussion; the same pattern is found in the Suliyman Paşa alfaransawī Mosque at Kūrnīsh al-nīl St. (1276A.H./ 1859A.D.), Hassan Paşa Ṭahir Mosque. Those of Hilal Bey Mosque are closed by veils of leathe wood like those of the Mosque of 'bdul 'ziz al-dirīnīi ${ }^{-18}$ in Manīl al-Rawḍa Qașr al- 'inn̄i (1291-1292A.H/ 1873-1874A.D.). In addition to the above-mentioned windows, there are small oval windows 'qamarriya' as those of the upper tiers' windows of Hilal Bey Mosque. Such windows are found in many historic mosques in Cairo during the $19^{\text {th }}$ century as the case of the oval window atop the mihrab of Mehmed 'alī Paşa Mosque.

Arches. Arches were largely used to crown the openings of the doors and windows, and also to distribute the ceilings loads on the perimeter walls. The first category of arches that atop the openings are basically including flat arch and segmental or depressed arch. Flat arches

\footnotetext{
${ }^{90}$ - hajaj, Altoraz alm 'mary walfany limasajid alqahira, p.44.

91 - Ibrahīm, Ala'thar alislamīh albaqia bi-sharq aldelta, 1995,pp208:209.

92 - hajaj, Altoraz alm 'mary walfany limasajid alqahira, p. 31.

93 - Albațway, Al 'ma'r aldenia alislamia albaqia bil-dilta, pp57;69.

94 - hajaj, Altoraz alm 'mary walfany limasajid alqahira, pp217;219

95 - Ibrahīm, Ala'thar alislamīh albaqia bi-sharq aldelta, pp208:209.

${ }^{96}$ Ibrahīm, Ala'thar alislamīh albaqia bi-sharq aldelta, pp205:206.

97 - hajaj, Altoraz alm 'mary walfany limasajid alqahira, pp57:59,196.

98 - ḥajaj, Altoraz alm 'mary walfany limasajid alqahira, pp113,219,22:26,85.
} 
usually topped of the openings of the doors and windows, atypical pattern in Islamic architecture. Such marble -or stone- flat arch that is atop the main entrance of the northwestern façade of Hilal Bey Mosque is found in many examples in the 19th century mosques of Cairo. These flat arches whether marble or stone, were adorned with writings and geometric decoration. As found in the mosque under discussion, the marble flat arch is used for the foundation inscription. The same pattern is found in the 19th century mosques in Cairo as in the Saīda Nafisa Mosque ${ }^{99}$ (1314A.H./ 1895A.D.). The stone flat arches atop the windows' openings of the façades of Hilal Bey Mosque are decorated with geometric motifs (Pl. 3).

Segmental arch is used in Hilal Bey Mosque for relieving arches above the openings of the doors and windows. The same pattern appears in the $19^{\text {th }}$ century mosques of Cairo as those of the openings of Bishtak Mosque at Pūr Saīd St. (1277-1278A.H/ 1860-1861A.D). Between the flat arch and the relieving arch is the tympanum 'nafees'. This composition is common in the the $19^{\text {th }}$ century mosques of Cairo such as the entrance to the Sebil of the Mosque of Shīkh Darwish 'shmawī at al-'ataba (1266-1267A.H/ 1849-1850A.D.). On the other hand, the pointed arches were used in the arcades of Hilal Bey Mosque. Pointed arches were also used in temporary Cairo mosques in the same position as in the Mehmed Bey almadbul Mosque, the Mosque of Shīkh Salih Abū hadid, ${ }^{100}$ and al-Tawfīqi Mosque ${ }^{101}$ at shuhada' al-qital St., Pūr Saīd (1303A.H. / 1885A.D.) as well.

The Minaret. Hilal Bey Mosque has a single minaret following the Ottoman provincial style, located at the northern corner of the northwestern façade. Unfortunately, the upper part of the minaret is missed, and only the base survives. An old photo depicted the minaret and shows that was composed of a square base topped by two calendric stories and ending with a conical top. A similar minaret is found at the Sulīman Paşa al-faransawī Mosque ${ }^{102}$ in Cairo, and al-Qaḍi Hussain $^{103}$ mosque in the Delta.

Columns. Marble columns were used in the arcades of the prayer hall of Hilal Bey Mosque. Marble columns were used widely for the same purpose in the $19^{\text {th }}$ century mosques of Cairo such as al-dwakhlī mosque, Shīkh șalih abū hadīd mosque's musalla and haram. The columns of the mosque under discussion have various bases; while those of the $1^{\text {st }}$ arcade next to the qibla wall are square like those in Hassan Paşa Tahir Mosque, those of the middle arcade are bell-like as those of the musalla of Shīkh Darwish 'ashmawī at 'shmawì St. al'ataba (1266-1267A.H/ 1849-1850A.D.). The columns' shafts in Hilal Bey Mosque are cylindrical like those of Imam Shafi'i Mosque. The columns' capitals in Hilal Bey Mosque are varied; those of the $1^{\text {st }}$ arcade are composite (Ionic and Corinthian styles) like those of Jawhar Al-īnī, assaīd Jawhar Lane (1229A.H./1814A.D.), while the ones of the middle arcade are Corinthian like those in the small prayer of Sulìman 'gha al-silhdar Mosque.

The mihrab columns, of Hilal Bey Mosque, have stone bases and cylindrical shafts. The same pattern is found in the $19^{\text {th }}$ century Cariene mosques as in Al-juharī Mosque at alMuskī (1262-1265A.H/ 1845-1848A.D.). The columns' capitals are Doric or Tuscan style like those of al-juharī Mosque ${ }^{104}$.

The Mihrab. Mihrabs were one of the most important architectural elements in mosque; because they define the plan and manage the distribution of its elements. The mihrab of the

\footnotetext{
99 hajaj, Altoraz alm 'mary walfany limasajid alqahira, pp20-21,206,234,254,256.

100 hajaj, Altoraz alm 'mary walfany limasajid alqahira, pp139-140,100,195,162.

${ }^{101}$ Ibrahīm, Ala'thar alislamīh albaqia bi-sharq aldelta, p.188

102 hajaj, Altoraz alm 'mary walfany limasajid alqahira, pp113-114.

103 Albațay, Al ma'r aldenia alislamia albaqia bil-dilta, pp37-45.

104 hajaj, Altoraz alm 'mary walfany limasajid alqahira, pp31,158,25,100,224,37,51,66-67.
} 
mosque under discussion is placed a bit southern the southeastern wall. The same pattern is found in $19^{\text {th }}$ century mosques of Cairo as the case of the stone mihrab in the Mosque of Shīkh Darwish 'ashmawī and that of al-qabr altawīl Mosque. ${ }^{105}$ The mihrab of Hilal Bey Mosque is protruded from the southeastern façade as the ones in some mosques in the Delta during the $19^{\text {th }}$ century such as the Mosque of Ahmad Nafi ${ }^{\prime}$ at Mit Ghamr-Daqahlia (1270A.H/ 1853A.D.) and al-Tawf $\overline{1} q \overline{1}$ Mosque $^{106}$ at shuhada' al-qital St. al- 'arab district at Pūr Saìd (1303A.H/ 1885A.D). The mihrab of the mosque under discussion is of stone like $19^{\text {th }}$ century Cariene 'arif Paşa Mosque at Tabbana St. (1282A.H/ 1864A.D.). The mihrab here is also painted as like other temporary mosques in Cairo as in the Imam Shafi'i Mosque. It has also a rectangular arched recess with a blind semi-circular arcade of seven camel-neck arches similar to that of Hassan Paşa Țahir Mosque. Moreover, the mihrab's niche is a nondecorated semi-circular one like that of Qūsūn Mosque. The mihrab's hood comes within a semicircular arch as the case of the mihrab of Mehmed 'ali Paşa Mosque. The arch of the mihrab under discussion is rests on two columns; each one has a rectangular stone base and a doric (Tuscan) capital. The same pattern is found in other mosques such as Al-Juhari Mosque. Regarding the mihrab of the musalla in Hilal Bey Mosque, it is a semicircular niche covered with a hood within a semicircular arch resembling the one of the Mosque of Shikh Salih Abū hadid ${ }^{107}$, as an example of the $19^{\text {th }}$ century Cariene mihrabs. Finally, the mihrab's hood is decorated with ray lines on gypsum as in the mihrab of al-u rabī Mosque (1219A.H/ 1804A.D.), and that of al- abbasī Mosque (1224A.H/ 1809A.D) in Rosetta. ${ }^{108}$

The Minbar. The minbar of the mosque under discussion presents an example of the Egyptian minbars, i.e. comprising a dome atop the djawsaq and another one above its door. Mainly, it consists of several parts, including the frontal door, risha, stairs lead to the Imam's seat, djawsaq covers the Imam's seat, and the rawda doors. The Imam's seat is decorated with embossing geometric figures and quadrilateral shapes within parts of a polygon engraved on wood. The frontal door of the minbar has two lateral sides, covered with a wooden dome. The same pattern is found in other $19^{\text {th }}$ century mosques in Cairo as the case of Hassan al-anwar Mosque ${ }^{109}$ (1280A.H/ 1863A.D.). The frontal door is arched with a parabolic arch and it is closed with four wooden shutters. The $19^{\text {th }}$ century Al-ma'inni Mosque $^{110}$ at Damietta (1238A.H/ 1821A.D) presents a similar example of the Delta mosques. The risha of the minbar is decorated with interlaced full, half and quarters of a polygon, similar to those of the mosques in Cairo such as al-shafi'i Mosque. The Imam's seat has a square plan; its sides are decorated with polygons like the ones of al-Shamia Mosque at Nubar St. (1315-1316A.H/ 1896-1897A.D.). The rawda doors are not decorated similar to those of the $19^{\text {th }}$ century mosques in Cairo as Hussīn Paşa Abī 'isb' at Hussīn al-qumrī lane (1288A.H/ 1870A.D). The minbar's djawsaq is covered with an onion-shape dome. Among the similar examples of the $19^{\text {th }}$ century mosques in Cairo is the Hassan Paşa Tahir Mosque $^{111}$, and also in the Delta as in the Great Mosque in Zagazig ${ }^{112}$ (1248A.H/ 1832A.D.).

Floors and Ceilings. Generally, the floors and the ceilings are important to help the mosques to functions perfectly; floors to keep the prayer hall clean, and the ceilings to protect the worshipers from the fluctuations of weather with flexibility of providing the interior with the

\footnotetext{
105 hajaj, Altoraz alm 'mary walfany limasajid alqahira, pp100-101,183.

${ }^{106}$ Ibrahīm, Ala'thar alislamīh albaqia bi-sharq aldelta, pp 187,171.

${ }^{107}$ hajaj, Altoraz alm 'mary walfany limasajid alqahira, pp177,225-226,25-26,241,84-85,66-67,158-159.

${ }^{108}$ Ḧasan, Almaharib fi mișr, 2006,p203

109 hajaj, Altoraz alm 'mary walfany limasajid alqahira, p172.

${ }^{110}$ Taman, Almanabir Albaqia fi Shark Aldelta, pp.26:29.

111 hajaj, Altoraz alm mary walfany limasajid alqahira, pp.226-228,270-271,190-191,26-27.

112 Ibrahīm, Ala'thar alislamīh albaqia bi-sharq aldelta, p162.
}

- 202 - Hilal Bey Mosque in Kūm Al-nūr, Daqahlia (1270 A.H/ 1853 A.D) 
needed light and ventilation. The floor of Hilal Bey Mosque is covered with ceramic tiles, as the $19^{\text {th }}$ century mosques in Cairo such as 'abdul 'ziz al-drīnī Mosque. While the mosque's ceiling is made of wood on wooden braces with decorated ends of geometric ornaments. The same pattern is found in the $19^{\text {th }}$ century mosques of Cairo and Delta as in Qūsūn Mosque, ${ }^{113}$ and al-Sharif Zawia ${ }^{114}$ in 'abyar.

The Lantern. Diverse covering types come in response of the different requirements of the mosque's architecture. In other words, it was a type of a treatment of the atmosphere to obtain natural indirect light. ${ }^{115}$ Hilal Bey Mosque has one lantern lights the prayer hall as found in the Sulīyman Paşa al-faransawī Mosque. It has a rectangular plan centers the middle rewaq similar to the one in Hassan Paşa Tahir Mosque. ${ }^{116}$ It contains rectangular arched windows topped with a segmental arch and closed with wooden shutters with glass. The same pattern is found in those of al-Qaḍ̄ Hussain Mosque, Sīdī 'abdurahīm Mosque and alSharif Zawia ${ }^{17}$ in 'abyar. The lantern is covered with a pyramid-like cover similar to that of the Mehmed Bey al-madbul Mosque. ${ }^{118}$

The Oratory 'Almusalla'. The attached musalla of Hilal Bey Mosque is located between the prayer hall and the latrines. This musalla is covered with a wooden ceiling on wooden bracers void of decorations. The $19^{\text {th }}$ Century mosques of Sulìyman Paşa al-faransawi $\overline{1}$, Aljuharī and Hassan Paşa Tahir are just examples of this pattern in Cairo. The niche of the mihrab centers its southeastern wall, it is a semi-circular recess topped with a semicircular arched hood, resembling the case of al-Hatū Mosque. ${ }^{119}$

The ablution fountain (lavatory). The architect was keen to build the ablution fountain (lavatory) separated from the prayer hall to keep the latter's purity and cleanness. Moreover, it was not built behind the qibla wall respecting the direction of the qibla; so it comes at a lateral corner to the prayer hall. It has a rectangular plan as in the Shirif Paşa al-kabīr mosque at Al-kirdasi St. (1277A.H/ 1860A.D.). The wooden ceiling of the lavatory of Hilal Bey Mosque rests on the walls and wooden braces, supported by sanbouksat and wooden columns. The same pattern is noticed in the $19^{\text {th }}$ century mosques of Cairo as in the lavatory of Jawhar al-īni. ${ }^{120}$

\section{DECORATIVE PATTERNS}

Inscriptions. Hilal Bey Mosque has one inscription; the foundation inscription atop the main entrance. It is written in Arabic in the thuluth script with embossing on marble. The foundation texts of some mosques in Cairo in the $19^{\text {th }}$ century were written in the same script, such as Hassan Paşa Tahir, al-'ahmar and al-barbarī mosques (1307A.H/ 1888A.D.). Writing the foundation text of Hilal Bik Mosque followed the system of lines; it comprised 3 lines. The $1^{\text {st }}$ and $2^{\text {nd }}$ lines contain three cartouches, while the $3^{\text {rd }}$ one has only two cartouches. Such kind of inscriptions were found widely in the $19^{\text {th }}$ century mosques of Cairo such as Mehmed 'alī Paşa and Saīda Nafísa.

Geometric Ornaments. The geometric ornaments varied including the stone bands, the rib, semi-cane ornament, concave quarter of a circle, reflected wave and convex quarter of a

\footnotetext{
113 hajaj, Altoraz alm 'mary walfany limasajid alqahira, p210,246.

114 Albațay, Al 'ma'r aldenia alislamia albaqia bil-dilta, p53.

${ }^{115}$ Waziry, al'imarh alislamīh walbiy'ah, p.131.

${ }^{116}$ hajaj, Altoraz alm 'mary walfany limasajid alqahira, pp117,27.

117 Albațay, Al ma'r aldenia alislamia albaqia bil-dilta, pp44,15,53.

118 hajaj, Altoraz alm 'mary walfany limasajid alqahira, p202.

119 hajaj, Altoraz alm mary walfany limasajid alqahira, p127.

120 ḥajaj, Altoraz alm 'mary walfany limasajid alqahira, p136,41.
} 
circle. They were widely used in adorning the entrances, windows, niches ...etc, such as in the Mosques of Sulīyman 'agha al-silhdar and Bishtak. Frets were used in framing the entrances of Hilal Bey Mosque. They were also utilized in the entrance of the 'abdul'ziz aldirīn̄ mosque and the main entrance of Hassan Paşa Țahir Mosque. Zigzag decoration was employed in the decoration of the stone mihrab niche in Hilal Bey Mosque, as well as other mosques in Cairo, including the mosque of Sulīyman 'agha al-silhdar. Polygons of 8 kendas adorn the frontal door of the minbar. The same pattern is used in the minaret, minbar, and dikat almobelgh of Saīda Nafisa Mosque. Additionally, the two sides of the minbar's frontal door are decorated with 10-kendas polygons. Shafi' $\overline{1}$ Mosque was an example of this decoration in the $19^{\text {th }}$ Century Cairo. The two risha of the Hilal Bik Mosque's minbar are decorated with 16-kendas polygons, as found in the courtyard's ceiling of Qūsūn Mosque. Furthermore, the back of the minbar's seat in Hilal Bey Mosque is decorated with a horseshoe arch and this decoration was used in other mosques in Cairo during the $19^{\text {th }}$ century, such as Sulīyman Paşa al-faransawī Mosque. ${ }^{121}$

The risha of the minbar in Hilal Bey Mosque is decorated with quadrilateral and pentagonal stars. For example, the ceiling of the vestibule of the Shamiya Mosque is decorated with pentagonal stars, while the shutters of the southwestern entrance of Qūsūn Mosque and the entrance of the chamber of the keeper were decorated with pentagonal stars. The main entrance of Hilal Bey Mosque has octagonal stars. Such element was found in the $19^{\text {th }}$ century mosques of Cairo as in Al-Juharī Mosque. The shutters of the main entrance of Hilal Bey Mosque are decorated with inclined mafrūk that was found in other mosques in Cairo during the $19^{\text {th }}$ century, as the case of the dome of Bishtak Mosque. ${ }^{122}$ It was also employed in the Delta mosques, including the shutters in the northwestern façade of Shīkh Manșur alFaham Mosque, ${ }^{123}$ Alexandria (1262A.H/ 1845A.D). The windows of Hilal Bey Mosque are surrounded by rhombuses. These shapes were found in the $19^{\text {th }}$ century mosques of Cairo as in the ceiling and braces of 'abī Dar' Mosque. The main wooden door and the inner part of the lantern of Hilal Bey Mosque are decorated with arrows' heads that were also used in other mosques of Cairo during the $19^{\text {th }}$ century, as in the minbar of the mosque of Hassan al'anwar at Misr al-qadima (1280 H./1863 A.D.). The upper segment of the arch of the main portal and the hood of the mihrab of the musalla in Hilal Bey Mosque are decorated with ray-lines; a typical pattern in the $19^{\text {th }}$ century mosques of Cairo with distinguished examples of Hassan Paşa Țahir and Bishtak mosques. ${ }^{124}$ The same decorations were also found in the Delta mosques as the case of the small windows of the northeastern and southwestern entrances of the Mosque of al-Ṣalīh Najm-u-ldīn Ayub ${ }^{125}$ in al-Manșura (13 ${ }^{\text {th }}$ A.H/ $19^{\text {th }}$ A.D. century).

The façade of the main entrance of Hilal Bey Mosque was decorated with the so-called mallet or deqmaq (al-kirandiz or al-kiranday); which was also found in the Delta $19^{\text {th }}$ century

\footnotetext{
${ }^{121}$ hajaj, Altoraz alm mary walfany limasajid alqahira, pp44-45,139,206,24-25,52,254-255,260263,228,250,115.

${ }^{122}$ hajaj, Altoraz alm 'mary walfany limasajid alqahira, pp269,235,67,145.

${ }^{123}$ Diqmaq, Almasajid albaqia fi aliskandaria, pp 17:127.

${ }^{124}$ hajaj, Altoraz alm 'mary walfany limasajid alqahira, pp 17,172-173,20,143.

${ }^{125}$ Albațay, Al ma'r aldenia alislamia albaqia bil-dilta, pp19:21.
}

- 204 - Hilal Bey Mosque in Kūm Al-nūr, Daqahlia (1270 A.H/ 1853 A.D) 
mosques as the case of the base of the minaret of 'abdul 'aziz Radwan Mosque in al-Zaqaziq, al-Sharqia (1339A.H/ 1920A.D). ${ }^{126}$ The stone $s a d r$ of the mihrab and the windows' frames of the façades of Hilal Bey Mosque were decorated with torsades, a common pattern in the $19^{\text {th }}$ century mosques of Cairo as in the ceiling of the southeastern iwan of Al-shamia Mosque. The rectangular recess of the mihrab of Hilal Bey Mosque was decorated with a 7arches blind arcade of the so-called camel-neck arches. Such arcade was appeared in the $19^{\text {th }}$ century mosques of Cairo as the case of the mihrab of Saīda Nafisa mosque, in which comes in a pointed and semi-circular arched form. The frontal door of the minbar of Hilal Bey Mosque is decorated with a painted crescent, the same pattern was also found in the $19^{\text {th }}$ century mosques in Cairo as in the ceiling of Jawhar al-aīnī Mosque. ${ }^{127}$

Foliate motifs. The columns' capitals of the arcade next to the qibla wall were decorated with acanthus leaves that were appeared in the $19^{\text {th }}$ century mosques of Cairo as the case of Bishtak mosque. ${ }^{128}$ Acanthus leaves were used in the $19^{\text {th }}$ century Delta mosques with a distinguished example of the columns of the northwestern entrance of al-taruți mosque, Faqūs, al-Sharqia (1355A.H/1936A.D). ${ }^{129}$ They were also found in the interior of the tomb attached to the Beshtak mosque. The foundation inscription of Hilal Bey Mosque was decorated with octagonal flowers. This motif appeared as well in the $19^{\text {th }}$ century mosques in Cairo as the case of the ceiling of the corridor of 'Abī Dar' Mosque and in the shutters of the main entrance and the minbar and the maqșura of the attached mausoleum of the Shikh Salih abū Hadīd Mosque. Finally, the foundation inscription of Hilal Bey Mosque is also decorated with dart dentate leaves; a pattern was used in the contemporary mosques of Cairo such as in the interior of the half domes of Mehmed 'Alī Mosque. ${ }^{130}$

\section{CONCLUSION}

Considering the above documentation and analysis of Hilal Bey Mosque, who was a senator in the Shoura Council at the time of Khedive Isma'il, we can now identify a number of results as follows: 1) Hilal Bey Mosque is a provincial ottoman mosque bears much local features; a typical pattern in the $19^{\text {th }}$ century mosques in Cairo and in the Egyptian provinces as well. 2) The plan of the mosque and more specifically the prayer hall comprises a rectangular area divided with aisles and covered with a wooden ceiling. 3) Yellowish limestone was used in the construction of the mosque was brought from the quarries of

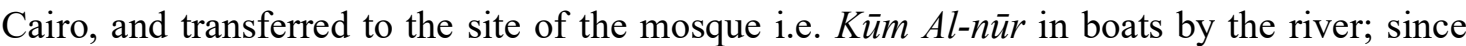
such quarries in the Delta were rare. 4) There is an iwan-form oratory attached to the mosque on its southeastern side. 5) the functionalism rather than the aesthetic aspect was the main factor in the design of the Hilal Bey Mosque; as appeared in the decentralization placement of the mihrab, the main entrance, and in the dissymmetrical distribution of the windows of the mosque's façades.

\footnotetext{
${ }^{126}$ Albațway, Al 'ma'r aldenia alislamia albaqia bil-dilta, p154.

127 hajaj, Altoraz alm 'mary walfany limasajid alqahira, pp274,259,40.

${ }^{128}$ hajaj, Altoraz alm 'mary walfany limasajid alqahira, p401.

129 Albațay, Al 'ma'r aldenia alislamia albaqia bil-dilta, p220.

${ }^{130}$ hajaj, Altoraz alm 'mary walfany limasajid alqahira, pp13,154,157,159-160,93.
} 


\section{REFERENCES}

- Abdelghany Alshal, Muṣtalahat fi alfan waltarbya alfania (in Arabic= Terms of Art and Art Education), King Saud University Press, Kingdom of Saudi Arabia, (1984).

- Abdelmonsef Nigm, Altoroz alm'maria walfania lebaad masakin alomaraa walbashawa fi Madinat alqahira fi alqarn altas 'ashar (in Arabic= The Architectural and Artistic Styles of Some Houses of Princes and Beys in Cairo in the $19^{\text {th }}$ Century), Ph.D., Faculty of Archaeology, Cairo University, (2000).

- Abdelmonsef Nigm, Dirasa hawl almadlolat alfalakia waldinia libad zakharif lībriq almansoub ila Marwan ibn Mehmed, General Union of Arab Archaeologists (in Arabic = A Study on the Astrological and Religious Connotations of some Decorations of the Pot Attributed to Marwan ibn Muhammad), Magazine of the General Union of Arab Archaeologists, vol. (3), Cairo ,(2002).

- Abdelmonsef Nigm, Shi'ar alothmanin 'la ala'ma'ir walfunon fi alqarnain althani 'shr walthalith 'shr alhijriian (18-19AD) wahata 'lsha alsaltana alu'thmania "dirasa atharia fania" ( in Arabic $=$ The Ottomans' Slogan in the Buildings and Arts of the $12^{\text {th }}$ snd $13^{\text {th }}$ Hijri (1819A.D.) Centuries till the Collapse of the Ottoman Sultnate "An Archaeological and Artistic Study), Journal of the Faculty of Arts, vol.(10), (2004).

- Abdelnaser Yaseen, alr'mzyh aldenyh fey alzkhrafh aleselameyh (derasa fi "meytafeyzeyqa" alfan aleselamey (in Arabic= The Religious Symbolism in the Islamic Architecture (A Study in the Metaphysics of Islamic Art), Zahraa Elsharq for Publishing, Cairo, (2006).

- Abdelrahman Alrafiy, 'Așr Isma'il (in Arabic= the Age of Isma'il), General Egyptian Book Organization, Cairo, (2000).

- Abdelrahman Alrafīy, 'Aṣr Mehmed 'Alī (in Arabic= The Age of Mehmed Ali), 5 st ed, Dar Almaaref, Cairo, (1989).

- Abdelrahman Zaki, Ala'lam wa sharat almulk fi wadi alnil (in Arabic= Flags and Kingship Signs in the Nile Valley), Dar Al Marref Bookstore, Cairo, (1949).

- Abdelrahman Zaki, Al'alam almiṣry (in Arabic= The Egyptian Flag), without Publisher, Cairo, (1940).

- Abdelsalam Nazîf, dirasat fì al'imara 'īslamīh (in Arabic= Studies in the Islamic Architecture), GEBO, Cairo, (1989).

- Abdelwahab hajaj, Altoraz alm'mary walfany limasajid alqahira fi alqarn althalith 'shar alhijri (1215-1318H.) altas' 'shar almelady (in Arabic= The Architectural and Artistic Style of Cairo's Mosques in the $13^{\text {th }}$ Hijri Century (1215-1318)/19 ${ }^{\text {th }}$ A.D. Century (18001899), Thesis, Faculty of Archaeology, Cairo University,( 2006).

- Abdullah Mousa, Tatawr alm'zana almisria bimadinat alqahira fi alfath al'arabi wahata nehayat al'sr almamluki- derasa m'maria zokhrofia moqarana m'a maazin ala'lam alislamia(in Arabic= The Development of Egyptian Minaret in Cairo from the Arab Conquest to the End of Mamluk Era-A Comparative Architectural Ornamental Study with the Minarets of the Islamic World), Ph.D., Faculty of Archaeology, Cairo University, (1994).

- Abdulsattar Abūhashim, fn ala'rkt (in Arabic= The Art of Wood Carving), Dar Altalae for Printing and Publishing, Cairo, (2004).

- Abdulsattar Alnīry, deras tariykhyh atharyh lemuhafazat aldqhelyah khelal al'sr aleselamey (in Arabic= A Historical and Archaeological Study of Dakahlia in the Islamic Era), Ph.D., Faculty of Women for Arts, Science and Education, Ain Shams University, (2003).

- Aesha Yusif, ashgh'l alurkham fē q'sr alameyr Mehmed Ali alemneyl- derash 'thryh $f$ 'nyhy (in Arabic= Marble Works in the Manial Palace of Prince Mehmed Ali- An 
Archaeological and ArtisticStudy), Thesis, Faculty of Archaeology, Cairo University, (2009).

- Afeef Bahnasi, "Ma'any alnujom fi alraksh al'raby" in Alfonon alislamia almabade' walashkal walmadamīn almoshtaraka (in Arabic= Star Signs in the Arab Decorations" in Islamic Arts: Principles, Shapes and Shared Implications), Dar Elfekr, Damascus, (1989).

- Ahmed Daqmaq, Masajid al-'skandariat al-baqiat fi al-qarnaīn al-thanī 'shar w-al-thalith 'shar $b$ 'd al-hijrat (in Arabic= The Remaining Mosques in Alexandria in the $12^{\text {th }}$ and $13^{\text {th }}$ Hijri Centuries), Thesis, Faculty of Archaeology, Cairo University, 1994.

- Ahmed Essa, Mostalahat alfan alislami (mo'jam mashrouh mosawar) ( in Arabic $=$ Terms of the Islamic Art (Illustrated Glossary), Research Center For Islamic History, Art and Culture, Istanbul, (1994).

- Ahmed Fikry, Masajid alqahira wamadarisha (Al șr alfatimiM) (in Arabic= Mosques and Schools of Cairo (the Fatimid Era)), Vol. (1). Dar Almaaref, Cairo, (1965).

- Ahmed Nașr, aluthaf alkhashabiah fĩ 'sr usrat Mehmed Ali fi da' majmat altuhaf alathabta walmanqulah almahfowzh bimthf qasr almanayl belqahera_dirasa atharih fanyh (in Arabic= Wooden Artifacts in the Reign of Mehmed Ali Dynasty in the Light of In the light of the Collection of Permanent and Movable Artifacts Preserved in the Museum of Manial Palace in Cairo- An Archaeological and Artistic Study), Thesis, Faculty of Archaeology, Cairo University, (2010).

- Ali Alțayish, Alfunon Alzokhrufia Alislamia Almobakira fi Alasrayn Alamawi wa Alabasi (in Arabic= The Early Islamic Decorative Arts in the Umayyad and Abbasid Eras), Zahraa Elsharq for Publishing, Cairo, (2013).

- Ameen Samy, Taqwim alnil (in Arabic= Nile Calendar), Vol.(4), $3^{\text {st }}$ ed. General Organization of Cultural Palaces, Cairo, (2009).

- Aml Alshahawy, Ba'd Mazahir Al-Tathirat Al-Bizantia 'Ia Al-Funon Al-Islamia fi AlThalathat Kuroun Aloula min Al-Higra (in Arabic=Some Forms of the Byzantine Effects on the Islamic Arts in the First Three Hijri Centuries), Thesis, Faculty of Archaeology, Cairo University, (2002).

- Asem Rizq, Muajam Mustalahat Al'imara wa Alfonon 'Tīslamīh (in Arabic= Dictionary of the Terms of Islamic Architecture and Arts), Madbouly Bookstore, Cairo, (2000).

- Attiat Saudy, al-rukham fi miṣr Dawlat al-mamalīk al-bahrīat "Dirasa 'tharia fan̄at (in Arabic= Marble in Egypt in the Era of Bahriyya Mamluks- An Archeaological Artistic Study), Ph.D., Faculty of Archaeology, Cairo University, (1994).

- Elias Alayoubi, Tarikh masr fi 'sm alkidiway Isma'l pasha min sanat 1863 ila sanat 1879(in Arabic= History of Egypt in the reign of Khedive Isma'il Pasha from 1863 to 1879), Vol. (1), Msbouly Bookstore, Cairo, (1996).

- Elsayed Ady Sheer, Mujam al-alfaz al-farisiat al-mu rabat (in Arabic= The Dictionary of Persian-Arabicized Vocabularies), Librairie Du Liban Publishers, Beirut, (1980).

- Enas hamdy, Dirasa fi 'İ'mara 'lislamīh (al'sala walshakhsia)( in Arabic=A Study of the Islamic Architecture (Originality and Personality), Thesis, Faculty of Engineering, Alexandria University, (1980).

- Ezzat Qadous, Tarikh 'am llfunon (in Arabic= A General History of Arts), n.p., Alexandria, (2011).

- Fareed Shaffî, Al'imara ala'rabia fi mișr 'Tislamīh (in Arabic= The Arabic Architecture in Islamic Egypt (Age of Rulers)), GEBO, Cairo, (2002).

- Ghadeer Khalefa, Aldawr alme'mary walfany llmoqarnasat fi ali'mara almmalokia bimisr wa-sham "dirasa atharia fania moqarana" (in Arabic= The Architectural and Artistic Role of Stalactites in the Mamluk Architecture in Egypt and the Levant "A Comparative Artistic and Archaeological Study), Thesis, Faculty of Archaeology, Cairo University, (2006). 
- Gorgey Zydan, Tarajim mashahīr a-sharq fi alqarn altasi' a'shar(in Arabic= Bibliographies of The East Celebrities in the $\mathbf{1 9}^{\text {th }}$ Century), Vol. (1), Hindawi Institution for Education \& Culture, Cairo, (2011).

- Hala Yusif, Derash athare'a lilanaser alzokhrufia wa-lasaleeb asensia 'Ia almangotat alhajaria walrukha bilmatahaf alqebty fil qarn alkhames almelady hata montasaf alqarn althany 'shar almelady (in Arabic= An Archaeological Study of the Ornamental Elements and Industrial Styles on the Stone and Marble Engravings in the Coptic Museum, Cairo from the $5^{\text {th }}$ to the Mid-12 ${ }^{\text {th }}$ Centuries), Thesis, Faculty of Archaeology, Cairo University, (1992).

- Hana Hasan, Almaharib fi misr fi ala'sr alothmany wa a'sr Mehmed Ali (923-1265H./15171848A.D (in Arabic= Mihrabs in Egypt in the Ottoman and Mehmed Ali Eras (9231265H./1517-1848A.D.)), Ph.D., Faculty of Archaeology, Cairo University, (2006).

- Hasan Abdulwahab, Tarikh almasajid alatharia bi-lqahira (in Arabic= History of archaeological mosques in Egypt), The Egyptian National Library and Archives, Cairo, (1946).

- hussīn Amīn, hussīn Salih ,Botrous Awadallah and Awadallah Alkiki, fn albina'( in Arabic= The Art of Building), Vol.(1), The General Organization for Government Printing Offices, Cairo, (1981).

- Ibraheem Hasanin, Ashghal alrukham fi al'mara aldinia fi Madinat alqahira fi 'hd Mehmed Ali wakhulafauh derasa atharia fania (in Arabic= Works of Marble in the Religious Buildings in Cairo in the Reign of Mehmed Ali and his Successors), Thesis, Faculty of Archaeology, Cairo University, (2007).

- Ismael Alboghdady, Hadiat Al'rifín (Asma' Almooalifin wa Athar Almosanifin)( in Arabic=Scholar's gift (authors' names and compilers' impacts)), vol.(2), Elmaaref Publisher, Istanbul ,(1955).

- Jamal Hasan, al-hulā̄at al-zukhrafĩat 'la 'mai'r al-qahirat fi al- ș̣r al-mamluk̄̄ al-jarkasī, (in Arabic= Ornamental Licentiousness in the Buildings of Cairo in the Mamluk jarkasi Period), Ph.D., Faculty of Archaeology, Cairo University, (1991).

- Kamal Almașry, Tarikh Alfan fi al sour al-qadìma (in Arabic=History of Art in the Ancient in the Ancient Eras), Dar Almaaref, Cairo, (1976).

- Keppel Creswell, The Muslim Architecture of Egypt, Trans: Abdulwahab Aloob and Mehmed hamza, Zahraa Elsharq for Publishing, Cairo, (2004).

- Mahmoud Alhussiny, Al'asbila alothmania albaqia bimadinat alqahira-derasa m'maria atharia (in Arabic= The Ottoman Public Drinkings Remaining in Cairo- An Architectural Artistic Study), Thesis, Faculty of Archaeology, Cairo University, (1982).

- Mahmoud Fahmy, almața' alquomria fi Alabnya Alaskria(in Arabic=Afflatus Adjustments in Comparing Hijri Dates to Georgian Calendar ), Manuscript in the Library of the Egyptian National Military Museum, 1275A.H. (1868).

- Maysa Dawood, Alkitabat ala'rabia 'la alathar alislamia monz alqarn alawal hata awakhir alqarn althany a'shar Ilhejra (6-18A.D.)(in Arabic= Arabic Engravings on the Islamic Monuments from the First Century to the late Twelve Hijri Century (6-18A.D.), Dar Alnahda Almașrya, Cairo, (1990).

- Mokhtar Alkasbany, Tatawr nuzum al'mara fi a'mal Mehmed Ali albaqea bimadinat alqahira(Development of the Systems of Architecture in the Remaining Works of Mehmed Ali in Cairo) (in Arabic= Development of the Systems of Architecture in the Remaining Works of Mehmed Ali in Cairo), Ph.D., Faculty of Archaeology, Cairo University, (1993).

- Mona 'Alī, Tarmim alṣouar aljidaria (in Arabic= Restoration of Wall Paintings), Zahraa Elsharq for Publishing, Cairo, (2003).

- Muhammad Abdulhafiz, Almostalahat alm'maria fi wathaiq 'sr Mehmed Ali wakholafauh 1805-1879 (in Arabic= Architectural Terms in the Documents of the Age of Mehmed Ali 
and his Successors 1805-1879), Egyptian Marketing \& Distribution Co. (EMDCO), Cairo, (2005).

- Muhammad Abūlfitouh, Madakhil al'mar almamloukia bilqahira aldinia walmadania min sanat 648H./1250 ila 784H./1382 (in Arabic= Entrances of Mamluk Buildings in Cairo: Religious and Civil from 648H./1250 to 784H./1382), Thesis, Faculty of Archaeology, Cairo University, (1975).

- Muhammad Alhadad, Bohoth wadirasat fi Al imara 'īslamīh(in Arabic=Researches and Studies in the Islamic Architecture), Nahdet Elsharq for Publishing, Cairo, (2000).

- Muhammad Alḥadad, Almadkhal ila dirasat almostalahat alfania lil'mara alislamia fi daw kitabat alrahala almoslimin wamoqaranta belnoqosh alatharia walnosos alwathaiqia waltarikhia (in Arabic=Introduction to the Study of Artistic Terms of the Islamic Architecture in Light of the Muslim Travelers' Writings Compared to the Archaeological Engravings and Documentary and Historical Texts), Zahraa Elsharq for Publishing, Cairo,(2008).

- Mustafa Alkhatib, Muajam AL-Mustalahat wa Al-ALqab Al-Tarikhi (in Arabic= Dictionary of Historical Terms and Titles, Damascus), Resalah Publishers, Damascus, (1996).

- Muhammad Alkihlawy, Athar mora'at itjah alqblah wa khat Tanzim altarik 'la mokhatatat al'amair aldinia almamlukia bimadinat alqahira (in Arabic=The Impact of Observing the Kiblah's Direction and Traffic on the Planning of Mamluk Religious Buildings in Cairo), Journal of Faculty of Archeology, Vol. (7), Cairo University,(1997).

- Muhammad Amīn and Layla Ibrahim, Almoștalahat alm 'amaria fi alwatha'q almamlukia (in Arabic= Architectural Terms in the Mamluk Documents), The American University in Cairo, Cairo, (1990).

- Muhammad hilmi, i'lm alm'adin (in Arabic= Metallurgy), The Anglo Egyptian Bookshop, Cairo, (2015).

- Muhammad Marzouq, Masajid alqahira qabl 'ṣr almam līk (in Arabic= The Mosques of Cairo before the Mamluk Era), Ataya Publisher, Cairo, (1942).

- Muhammad Mokhtar, Altawfikiat 'Īlhamya fi mokarint Altawarikh Alhijria bilsinin 'liffrankia walajnabia(in Arabic= Skylight stairs at the military buildings), Arab Institute for Research \& Publishing, Cairo, (1980).

- Muhammad Najib, Madrasit ala'mir Kabir Qirqmas wa molhaqatiha- dirasa m'maria waatharia (in Arabic= The School of Prince Kabeer Qernas and its Attachments- An Architectural and Archaeological Study), Ph.D., Faculty of Archaeology, Cairo University, (1975).

- Muhammad Najib, Madrasit Khayrbak bi-bab Alwazir (in Arabic= Khayrbak school in Bab Elwazir), Thesis, Faculty of Archaeology, Cairo University, (1968).

- Muhammad Ramzy, Alqamous Algoghrafi Lilbilad ALmisria min 'hd Kodamaa ALmasrīn ila 1945 (in Arabic= The Geographical Dictionary of the Egyptian Cities from the Ancient Egyptians to 1945 ), Vol. (1/2), General Organization of Cultural Palaces, Cairo, (2010).

- Muhammad Sabry, Tarikh Misr Alhadith min Mohammed Ali ela Alyawm Mehmed Ali ila Alyaum (in Arabic= Modern History of Egypt from the Age of Mehmed Ali till Today), The Egyptian National Library and Archives, Cairo, (1926).

- Muhammad Taman, Almanabir Albaqia fi Shark Aldilta "Dirasa Atharia Fania" (in Arabic= The Minbars Remaining in Eastern Delta "An Artistic Archaeological Study), Thesis, Faculty of Arts, Tanta University, (2006).

- Mustafa Barakat, Alalqab walwazaif alu'thmania (derasa fi tatawr alalqab walwazaef monz alfath al'thmany limisr hata ilgha alkhilafa alu'thmania (min khilal alathar walwathaiq walmakhtotat (in Arabic= A Study of Calligraphy, Titles and Positions through the Remaining Foundation Texts of the Ottoman Buildings in Cairo), Dar Ghareeb for Printing, Publishing and Distribution, Cairo, (2000). 
- Neamat Abūbakr, Almanabir fi misr fi al'srain almamloky walturki (in Arabic= Minbars in Egypt in the Mamluk and Turkish Eras), Ph.D., Faculty of Archaeology, Cairo University, (1985).

- Noha Albațway, al-'mai'r al-'slamiat al-baqiat bildilta fi al-nișf al-thañ̄ min al-qarn 13H./19A.D. hatta nihayat al-nisf al-'wal min al-qarn 14H./20A.D. "Dirasa 'tharia m 'maia" (in Arabic= The Islamic Religious Buildings Remaining in Delta in the 2nd Half of the 13th H./19th A.D. Century till the 1st Half of the 14th H./20th A.D. "An Archetectural Archaeological Study), Thesis, Faculty of Arts, Tanta University, (2016).

- Rabee Khalefa, fonoun alqahia fi al'hd alothmany 923H/1517A.D.- 1220H./1805A.D (in Arabic= Cairo's Arts in the Ottoman Era 923H/1517A.D.- 1220H./1805A.D), Zahraa Elsharq for Publishing, Cairo, (2001).

- Rajab Ezzat, Tarikh alathath mondh aqdam al'uṣr (in Arabic= The History of Furniture since Ancient Times), GEBO, Cairo, (1978).

- Salih Lamey, Altorath alm mary 'līslami fi mișr (in Arabic= Islamic Architectural Heritage in Egypt), Dar Alnahda Alarabia, Beirut, (1984).

- Samy Bishay, Farouk Ibrahīm and Mohammed Abdulmigīd, Tarikh althakhrafa (in Arabic= History of Decoration), Elshorouq Publishing, Cairo, (1992).

- Shadia Kishk, Ashghal alkhashab fi al'amair al'othmania bimadinat alqahir "derasa atharia fania" (in Arabic=Woodworks in the Ottoman Religious Establishments in Cairo “An Artistic Archaeological Study"), Thesis, Faculty of Archaeology, Cairo University, (1984).

- Shehabeledeen Albaghdady, Moajam alboldan (in Arabic= Dictionary of Countries), Vol. (2), Dar Sader, Beirut, (1977).

- Sohair Ibraheem, al-'thar al-'slamiat al-baqiat bisharq al-dilta munzu al-fath al-'thmā̄ hatta nihayat al-qarn al-tas' 'shar (in Arabic= The Islamic Monuments Remaining in Eastern Delta from the Ottoman Conquest to the End of the $19^{\text {th }}$ Century), Ph.D., Faculty of Archaeology, Cairo University, (1995).

- Taha Omara, Al'anasir alzokhrofia almostakhdama fi 'marit masajid alqahira fi al'asr al'thmani (in Arabic= Ornamental Elements in the Construction of Cairo Mosques in the Ottoman Era), Ph.D., Faculty of Archaeology, Cairo University, (1988).

- Yahya Waziry, al'imarh 'līslamīh walbiy'ah (in Arabic= Islamic Architecture and Environment), Elseasa Publishing, Kuwait, (2004).

- Zaki Hasan, Fonon 'lislam (in Arabic= The Arts of Islam), Dar Alnahda, Cairo, (1948).

- Zaki Ḥasan, Ațlas alfonon alzokhrofia waltasawīr 'Tīslamīh (in Arabic= Atlas of Decorative Arts and Islamic Paintings), Dar Al Raed Al Arabi, Beirut, without date. 